\title{
Quantitative and
}

Qualitative Analysis

of the Family

Bolivinidae

GEOLOGICAL SURVEY PROFESIONAL PAPER 429-A

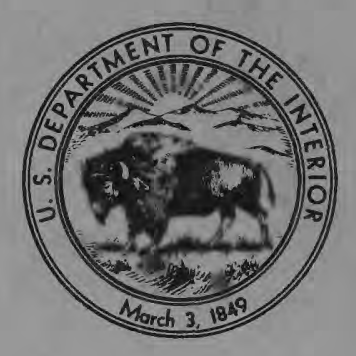




\section{Quantitative and}

Qualitative Analysis

of the Family

Bolivinidae

By PATSY B. SMITH

RECENT FORAMINIFERA OFF CENTRAL AMERICA

GEOLOGICAL SURVEY PROFESIONAL PAPER 429-A

A study based primarily on 22 core samples

collected at ocean depths of 20 to 3,200

meters on 2 traverses off the coast of El Salvador

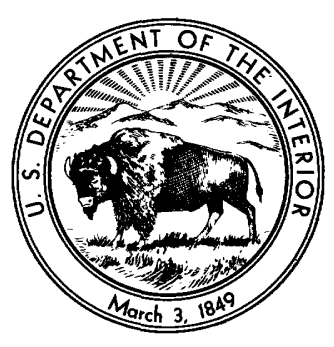

UNITED STATES GOVERNMENT PRINTING OFFICE, WASHINGTON : 1963 


\section{UNITED STATES DEPARTMENT OF THE INTERIOR \\ STEWART L. UDALL, Secretary \\ GEOLOGICAL SURVEY \\ Thomas B. Nolan, Director}

For sale by the Superintendent of Documents, U.S. Government Printing Office Washington 25, D.C. 


\section{CONTENTS}

Abstract

Introduction

Acknowledgments

Frevious work

Sampling technique and laboratory proce

Description of sampled area

Sampling technique.

Hydrographic data.............................

Bottom-water samples...........

Hydrographic stations

Organic nitrogen

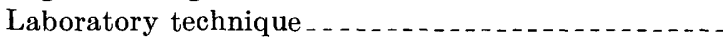

Quantitative and qualitative analysis

Quàntitative methods

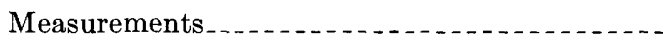

Statistical characterizations . . . . . . . . . .

Methods and significance..............

Relation of sample to population. . .....

Living specimens .........................

Reproducibility of quantitative data $\ldots . . . . .$. Measured samples .

\begin{tabular}{r|r} 
Page & A1 \\
1 & \\
1 & \\
2 & \\
2 & \\
2 \\
2 \\
5 \\
5 \\
5 \\
5 \\
10 \\
11 \\
12 \\
12 \\
12 \\
12 \\
13 \\
14 \\
14 \\
14
\end{tabular}

Page

Quantitative and qualitative analysis-Continued Quantitative methods-Continued Reproducibility of quantitative data-Con.

Measurements........... A14

Calculations

Systematic descriptions..........

Genus Bolivina d'Orbigny _..._....... 14

Subgenus Bolivina sensu stricto_........ 15

Subgenus Loxostomum

Genus Suggrunda. Hoffmeister and Berry _.....- 24

Faunal distribution. . . . . .

Conclusions_..._.

Faunal uniformity . .

Accumulation of samples _.................. 27

Statistical differentiation of species_............ 27

Variation within species with depth ............. 28

Ecologic factors _. _.

Applicability of results to fossil Cenozoic forms_.... 33

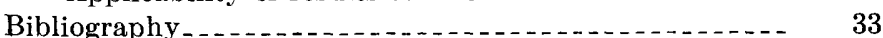

Index

\section{ILLUSTRATIONS}

[Plates 1-28 in pocket; plates 29-31 follow index]

Plates 1-18. Quantitative data for species of Bolivinidae.

1. Bolivina (Bolivina) seminuda Cushman.

2. B. (Bolivina) humilis Cushman and McCulloch.

3. B. (Bolivina) pacifica Cushman and McCulloch.

4. B. (Bolivina) argentea Cushman.

5. B. (Bolivina) interjuncta bicostata Cushman.

6. B. (Bolivina) semiperforata Lewis Martin.

7. B. (Bolivina) striatula Cushman.

8. B. (Bolivina) minuta Natland.

9. B. (Bolivina) subadvena Cushman.

10. B. (Bolivina) tongi filacostata Cushman and McCulloch.

11. B. (Bolivina) acuminata Natland.

12. B. (Bolivina) vaughani Natland.

13. B. (Botivina) inflata Heron-Allen and Earland.

14. B. (Bolivina) pseudobeurichi Cushman.

15. B. (Bolivina) bradyi Asano.

16. B. (Loxostomum) boltovskoyi $\mathrm{n} . \mathrm{sp}$.

17. B. (Loxostomum) salvadorensis $\mathrm{n}$. $\mathrm{sp}$.

18. Suggrunda eckisi Natland.

19-27. Quantitative data for samples.

19. Sample $\mathrm{C}-6$ ( 80 meters).

20. Sample C-17 (82 meters).

21. Sample $\mathrm{C}-16$ (144 meters).

22. Sample C-15 (435 meters).

23. Sample C-8 (450 meters).
Plates 24. Sample C-14 (800 meters).

25. Sample C-9 (885 meters).

26. Sample C-13 (1,600 meters).

27. Sample $\mathrm{C}-10$ (1,700 meters).

28. Key to qualitative and quantitative variations of species of Bolivinidae.

29, 30. Species of Bolivina.

31. Species of Bolivina and Suggrunda. Page

Figure 1. Map of area sampled and index map...... A3

2. Depth, temperature, and chemical profiles of bottom samples......................

3. Hydrographic data: temperature .........

4. Hydrographic data: $\mathrm{pH}_{\text {. .............. }}$

5. Hydrographic data: oxygen

6. Hydrographic data: salinity

7. Hydrographic data: Shuttle expedition....

8. Distribution and range of bolivinid species.

9. Bar graph showing parameters of range and mean

10. Triangular diagram showing percentage contribution of length, number of pairs of chambers, and length to width: Bolivina seminuda group.

11. Triangular diagram showing percentage contribution of length, number of pairs of chambers, and length to width: Bolivina argentea group. 
Page

Figdre 13. Triangular diagram showing percentage contribution of length, number of pairs of chambers, and length to width: Bolivina pseudobeyrichi group................
Page tribution of length number of pairs of chambers, and length to width: Bolivina

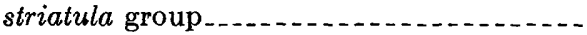

\section{TABLES}

Page

TABLE 1. Geographic coordinates of cores ............

2. Depth, temperature, and chemical data for bottom-water samples.................

3. Percentage of nitrogen in core samples.......
A2

5

10
Table 4. Percentage of nitrogen in core samples taken by the Hannibal expedition in 1935, off the coast of Nicaragua, Central America.......
Page

A 10 


\title{
RECENT FORAMINIFERA OFF CENTRAL AMERICA QUANTITATIVE AND QUALITATIVE ANALYSIS OF THE FAMILY BOLIVINIDAE
}

\author{
By Patsy B. Smith
}

\begin{abstract}
This paper is part one of a study of Recent foraminiferal faunas collected off the coast of El Salvador. The study is based primarily on 22 core samples taken on two traverses, from depths of 20 to 3,200 meters. Additional data (temperature, $\mathrm{pH}$, oxygen, and salinity) were obtained from bottom-water samples and hydrographic-station samples. Nitrogen values were obtained for the bottom samples and comparative values are taken from unpublished data on cores taken by the U.S. Navy vessel H annibal off Nicaragua in 1935.

For this report, all Bolivinidae were picked from the samples. The specimens are assigned to 17 species of Bolivina ( 2 new, $B$. boltovskoy $i$ and $B$. salvadorensis, both belonging to the subgenus Loxostomum) and 1 species of Suggrunda. The species are described qualitatively and quantitatively. For the nine samples in which Bolivinidae are very abundant, statistical characterizations were made, showing length, width, number of chambers, and proloculus diameter. The data are recorded on univariate and bivariate diagrams, which show the growth characteristics of species at different depths. Similar diagrams are given which show the variation between species in each sample.

The quantitative data indicate that (a) quantitative analysis assists in defining species; (b) within the area studied, samples from similar depths contain faunas that are similar quantitatively as well as qualitatively ; (c) samples in this area represent indigenous deposits rather than sediments emplaced by downslope movements; and (d) in some species, size, shape, or other features vary with depth: the largest and most abundant forms are found at a depth of about $800-900$ meters; other species do not vary with depth. The factors that cause variation with depth apparently are abundance of organic matter (estimated from nitrogen content), dissolved oxygen content, and perhaps temperature.
\end{abstract}

\section{INTRODUCTION}

This paper is the first part of a report on Recent foraminiferal faunas collected off the coast of El Salvador. The Pacific coast of Central America was selected for study because of the need for data on the Recent tropical faunas of the eastern Pacific; faunas from that area were known to have general affinities with the Tertiary faunas of southern California. The region off El Salvador was chosen for two reasons. Relatively short traverses include the entire width of the continental shelf and slope, and the bottom deposits are mostly of volcanic detritus and hence are free from contamination by reworked fossil Foraminifera.

At the outset of work on the samples, it became clear that several other problems might be studied to advan- tage. The pattern of cores allowed a check on the uniformity of faunas from approximately the same ecologic conditions. Also, the presence of living forms in most of the samples permitted a check on the everpresent possibility of large-scale transportation of dead specimens down the continental slope. Furthermore, the quantity and quality of the Foraminifera from a large range of depths encouraged a reexamination of the question: What variations can be demonstrated within a species from one depth to another? To help solve these problems, and simultaneously to demonstrate the usefulness of some of the simpler quantitative techniques in the study of Foraminifera, a statistical study was undertaken. The family Bolivinidae was chosen for this purpose; specimens of this group are easily measured, are abundant, and occur over a wide depth range.

\section{ACKNOWLEDGMENTS}

This work was made possible by the generous cooperation of the Scripps Institution of Oceanography. Sampling was done from the Scripps vessel Spencer $F$. Baird, on the Eastropic expedition, through the courtesy of R. R. Revelle, director of the Institution, and Townsend Cromwell and Warren Wooster, who planned and organized the expedition. Max Silverman and Ray Ghelardi bore the heavy burden of coring. Water analyses were made by N. W. Rakestraw and D. M. Brown of Scripps Institution. Nitrogen analyses on the bottom samples were made by the Hazelton Nuclear Science Laboratory, E. J. Forslow, analyst. Data on nitrogen off Central America was made available by Dr. Revelle.

Heinz Lowenstam of the California Institute of Technology furnished much helpful comment. O. L. Bandy of the University of Southern California helped greatly by allowing examination of his eastern Pacific material.

Several members of the Geological Survey contributed to the paper by frequent discussions and by reviewing parts of the manuscript. Special acknowledgment is due to A. O. Woodford, P. E. Cloud, Jr., and G. I. Smith. 


\section{PREVIOUS WORK}

Foraminiferal studies relating to the area are few. The earliest work was done by Göes (1896) who described and figured species from the Pacific coast of Central America. Coryell and Mossman (1942) described the fauna of the Pliocene Charco Azul formation of Panama, which is closely related to Recent faunas. Natland (1950) described the Pliocene sediments of the Gulf of California and included Recent ranges for many species. Bandy and Arnal (1957) discussed the distribution of Recent Foraminifera off the west coast of Central America.

Many papers describe the use of statistical methods in paleontology and zoology; a few of these consider Foraminifera. The general works found most helpful were Simpson and Roe (1939), Kermack (1954), and Imbrie (1956).

Cushman and Todd (1941) discuss stratigraphic variation in a species of Bolivina. Nicol (1944) divided Recent Elphidiums from the Pacific coast into several new species and subspecies on the basis of quantitative analysis.

\section{SAMPLING TECHNIQUE AND LABORATORY PROCEDURES}

\section{DESCRIPTION OF SAMPLED AREA}

Sampling was done in December 1955, from the Scripps Institution of Oceanography vessel Spencer $F$. Baird. The area sampled (see map, fig. 1) is off the Gulf of Fonseca, between El Salvador and Nicaragua. The gulf is a large rather shallow bay, with a tide of about 12 feet. Several large rivers, which drain an area composed entirely of volcanic rocks (Williams and Meyer-Abich, 1955), discharge into the gulf. Many active or recently active volcanoes surround the bay; this part of Central America is one of the most volcanically active areas of the world. In 1835, Conseguina (Nicaragua; see map, fig. 1) erupted, spreading a thick blanket of ash for tens of miles over land and sea (Russell, 1910, p. 158-164). The exclusively volcanic nature of the rocks eliminates the possibility of contamination by Foraminifera reworked from older marine sedimentary rocks.

\section{SAMPLING TECHNIQUE}

Two sampling traverses, nearly coincident, each about 100 miles long, were made across the continental shelf and down the continental slope (figs. 1 and 2). Samples were fairly evenly spaced across the shelf, and were taken at regularly increasing depth intervals on the slope. Depths were indicated by a continuously recording fathometer; stations on the inbound traverse were located as nearly as possible at the same depths as those of the outbound traverse. Eleven core samples were taken on each traverse. The geographic positions of coring stations are given in table 1 . Figures 1 and 2 and table 1 show how closely the samples were paired.

\begin{tabular}{|c|c|c|c|}
\hline Core & USGS Location & $\begin{array}{c}\text { Latitude } \\
(N .)\end{array}$ & $\begin{array}{c}\text { Longitude } \\
(W .)\end{array}$ \\
\hline C-1. & Mf 380 & $13^{\circ} 06.0^{\prime}$ & $87^{\circ} 48.4^{\prime}$ \\
\hline $\mathrm{C}-2$ & Mf 381 & $12^{\circ} 58.6^{\prime}$ & $87^{\circ} 51.1^{\prime}$ \\
\hline $\mathrm{C}-3$ & Mf 382 & $12^{\circ} 53.7^{\prime}$ & $87^{\circ} 53.1^{\prime}$ \\
\hline C-4 & Mf 383 & $12^{\circ} 48.9^{\prime}$ & $87^{\circ} 54.6^{\prime}$ \\
\hline $\mathrm{C}-5$ & Mf 384 & $12^{\circ} 40.0^{\prime}$ & $87^{\circ} 57.9^{\prime}$ \\
\hline $\mathrm{C}-6$ & Mf 385 & $12^{\circ} 33.2^{\prime}$ & $88^{\circ} 00.8^{\prime}$ \\
\hline $\mathrm{C}-7$ & Mf 386 & $12^{\circ} 20.2^{\prime}$ & $88^{\circ} 069^{\prime}$ \\
\hline $\mathrm{C}-8$ & Mf 387 & 12 $13.7^{\prime}$ & $88^{\circ} 09.0^{\prime}$ \\
\hline $\mathrm{C}-9_{-}$ & Mf 388 & $12^{\circ} 09.7^{\prime}$ & $88^{\circ} 10.4^{\prime}$ \\
\hline $\mathrm{C}-10$ & Mf 389 & $12^{\circ} 01.5^{\prime}$ & $88^{\circ} 12.3^{\prime}$ \\
\hline $\mathrm{C}-11$ & Mf 390 & $11^{\circ} 51.0^{\prime}$ & $88^{\circ} 16.3^{\prime}$ \\
\hline $\mathrm{C}-12$ & Mf 391 & $11^{\circ} 53.0^{\prime}$ & $88^{\circ} 14.2^{\prime}$ \\
\hline $\mathrm{C}-13$ & Mf 392 & $12^{\circ} 02.7^{\prime}$ & $88^{\circ} 10.8^{\prime}$ \\
\hline $\mathrm{C}-14$ & Mf 393 & $12^{\circ} 10.2^{\prime}$ & $88^{\circ} 08.8^{\prime}$ \\
\hline $\mathrm{C}-15$ & Mf 394 & $12^{\circ} 12.0^{\prime}$ & $88^{\circ} 08.2^{\prime}$ \\
\hline $\mathrm{C}-16$ & Mf 395 & $12^{\circ} 19.0^{\prime}$ & $88^{\circ} 05.6^{\prime}$ \\
\hline & Mf 396 & $12^{\circ} 33.0^{\prime}$ & $88^{\circ} 01.4^{\prime}$ \\
\hline $\mathrm{C}-1$ & Mf 397 & $12^{\circ} 40.8^{\prime}$ & $87^{\circ} 59.6^{\prime}$ \\
\hline $\mathrm{C}-$ & Mf 398 & $12^{\circ} 49.7^{\prime}$ & $87^{\circ} 57.5^{\prime}$ \\
\hline $\mathrm{C}-\mathrm{2}$ & Mf 399 & $12^{\circ} 55.9^{\prime}$ & $87^{\circ} 56.1^{\prime}$ \\
\hline $\mathrm{C}-$ & Mf 400 & $13^{\circ} 01.4^{\prime}$ & $87^{\circ} 54.8^{\prime}$ \\
\hline$C$ & Mf 401 & $13^{\circ} 04.9^{\prime}$ & $87^{\circ} 53$. \\
\hline
\end{tabular}

On the first traverse, four stations were occupied for hydrographic observations, and water samples were taken from various depths. Bottom-water samples were taken from the top of the core barrel. For all water samples, temperature, dissolved-oxygen content, salinity, and $\mathrm{pH}$ were determined by the methods described in Scripps Institution of Oceanogxaphy report 56-28 (1956).

Cores were taken with a 2-inch-diameter gravity-type coring device lined with a plastic liner. After coring, the liner containing the core was removed from the barrel and most of the supernatant water was siphoned off for analysis. The remaining water was siphoned off into a polyethylene bag, to which the top centimeter of the core was added. Methyl alcohol (70 proof) was added and the bag was bottled. The material in the bag was used for the foraminiferal studies. The remainder of the core was sealed into the liner and frozen, and was retained by Scripps Institution.

Poor cores were recovered from samples $\mathrm{C}-3, \mathrm{C}-5$, and $\mathrm{C}-21$ because shells or coarse clastic material held the blades of the core-catcher apart, which caused loss of a part of the core. Samples C-7 and C-16 were taken near the break between slope and shelf, and cores were short with most of the fine material lost. Water was lost from these five samples; so no analyses could be made. 


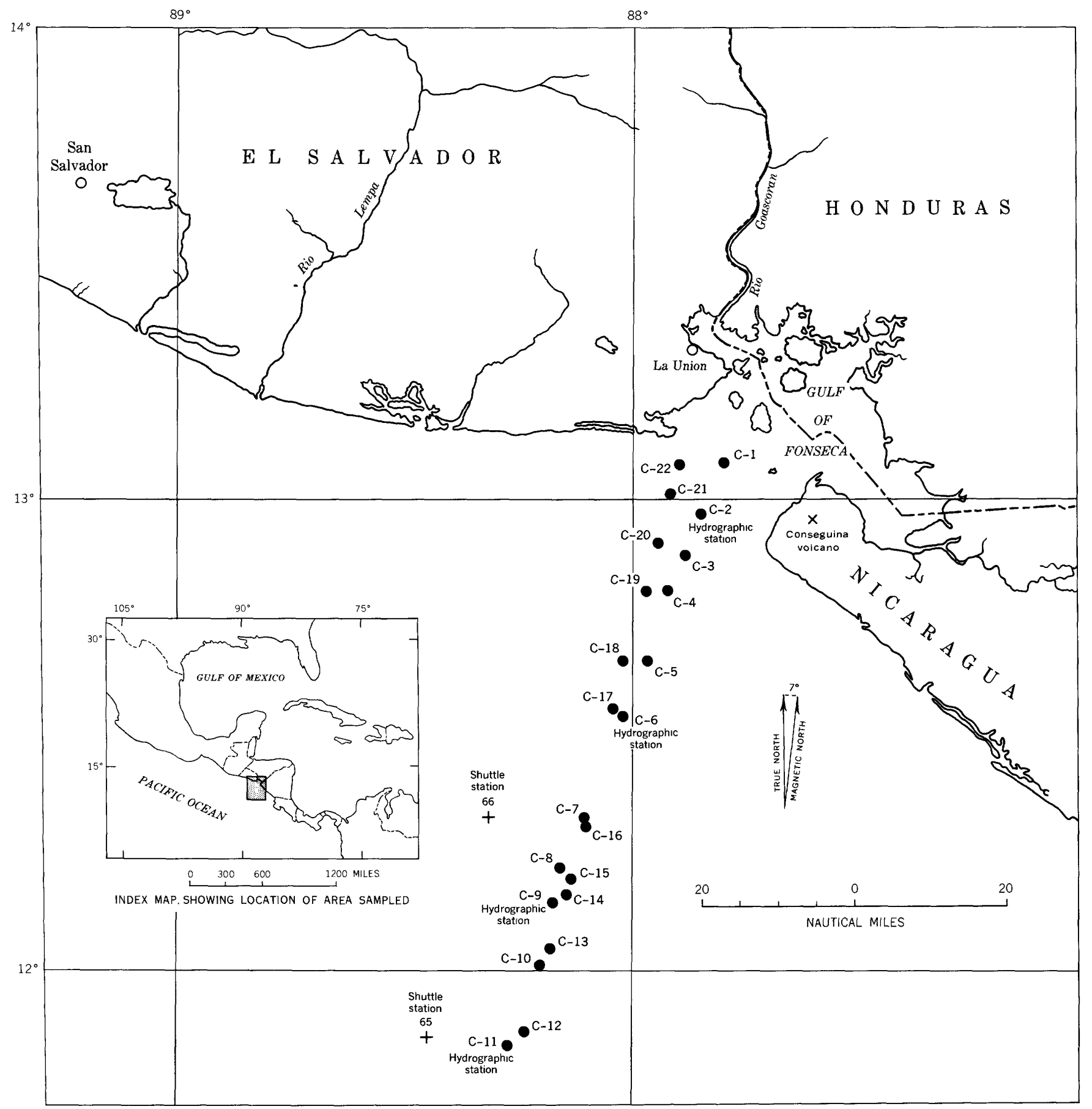

FIGURE 1.-Index map showing the coast of El Salvador, Nicaragua, and Honduras, locations where samples were taken, and hydrographic stations. 


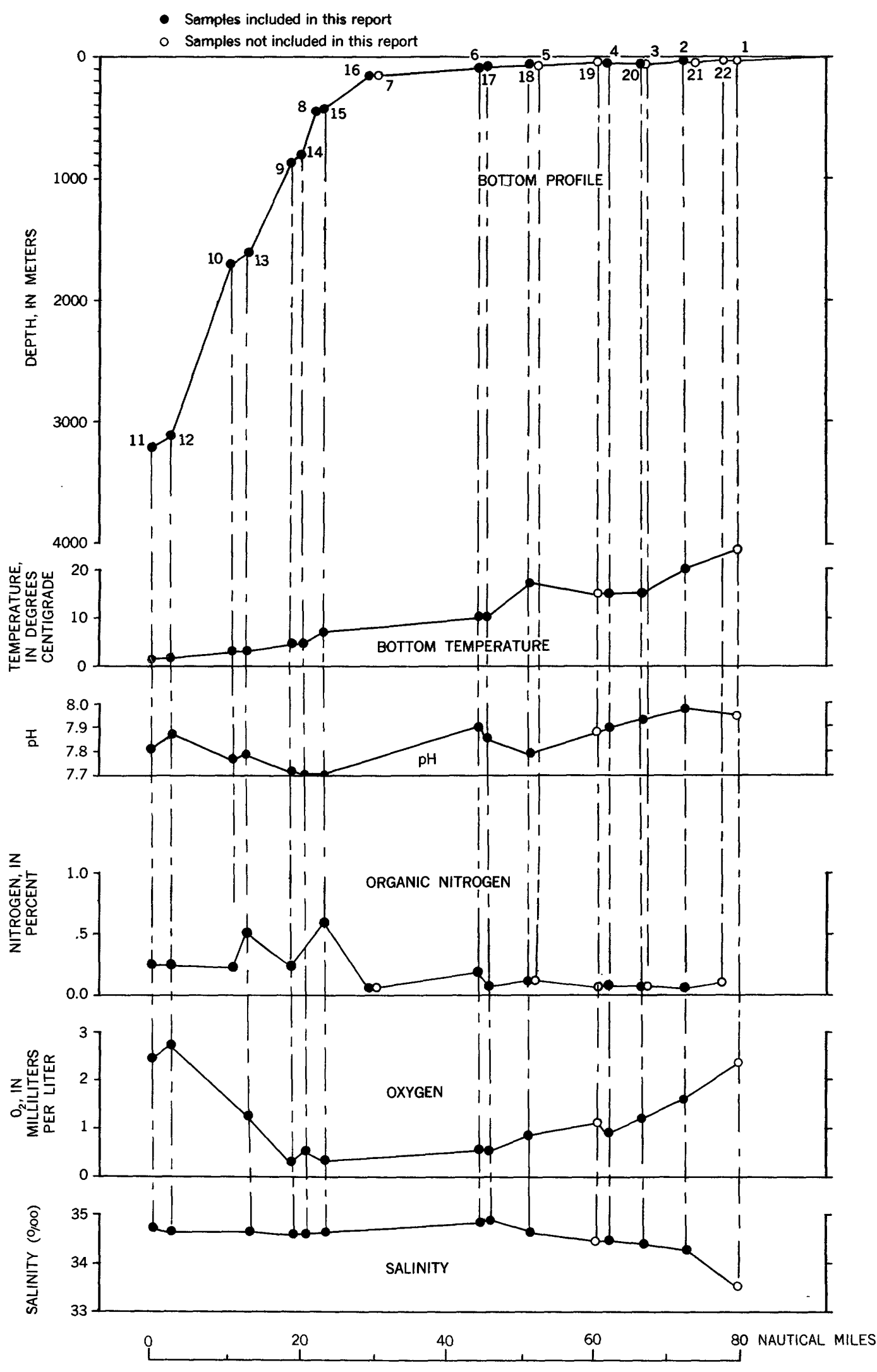

Figure 2.-Depth, temperature, and chemieal profiles of bottom samples. 


\section{HYDROGRAPHIC DATA}

At the hydrographic stations, water samples were collected in Nansen bottles equipped with reversing thermometers. Temperatures of bottom-water samples were determined before the samples were removed from the core barrel. Water from the Nansen bottles was analyzed for salinity, chlorinity, $\mathrm{pH}$, and dissolved oxygen content, and the same determinations were made on bottom samples of sufficient volume.
BOTTOM-WATER SAMPLES

Data from bottom samples are plotted on figure 2 and listed in table 2. Bottom temperature decreases fairly uniformly with increase in depth, to a low value of $1.7^{\circ} \mathrm{C}$ at the greatest depth $(3,200 \pm$ meters $)$. The $\mathrm{pH}$ values are irregular, with a marked minimum at 800 meters, below which there is a sharp rise. Salinity shows a gradual increase with depth.

TABLE 2.-Depth, temperature, and chemical data for bottom-water samples

[Determinations by N. W. Rakestraw and D. M. Brown]

\begin{tabular}{|c|c|c|c|c|c|c|c|}
\hline Sample & Depth (meters) & $\begin{array}{l}\text { Temperature } \\
\left({ }^{\circ} \mathrm{C}\right)\end{array}$ & Salinity $(\%)$ & Oxygen (ml per l) & $\mathrm{pH}$ & $\begin{array}{c}\text { Core length } \\
\text { (inches) }\end{array}$ & Type of sediment \\
\hline 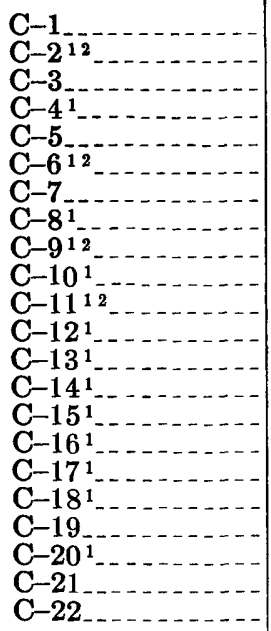 & $\begin{array}{c}20 \\
37 \\
46 \pm \\
50 \pm \\
74 \pm \\
80 \\
140 \\
450 \\
885 \pm \\
1,700 \pm \\
3,200 \pm \\
3,100 \pm \\
1,600 \pm \\
800 \pm \\
435 \pm \\
144 \pm \\
82 \pm \\
64 \pm \\
50 \pm \\
47 \pm \\
45 \\
21 \pm\end{array}$ & $\begin{array}{l}24 \\
20 \\
15 \\
10 \\
5 \\
3 \\
1.7 \\
1.7 \\
3 \\
5 \\
7 \\
10 \\
17 \\
15 \\
15\end{array}$ & $\begin{array}{l}33.51 \\
34.29 \\
34.47 \\
34.81 \\
34.56 \\
34.68 \\
34.60 \\
34.61 \\
34.57 \\
34.63 \\
34.83 \\
34.64 \\
34.47 \\
34.43\end{array}$ & \begin{tabular}{r}
2.35 \\
1.64 \\
.92 \\
.61 \\
\hdashline .90 \\
2.48 \\
2.72 \\
1.28 \\
.54 \\
.38 \\
\hdashline .58 \\
.86 \\
1.15 \\
1.22
\end{tabular} & $\begin{array}{l}7.95 \\
7.98 \\
7.90 \\
7.90 \\
7.72 \\
7.77 \\
7.82 \\
7.87 \\
7.79 \\
7.70 \\
7.71 \\
7.86 \\
7.79 \\
7.87 \\
7.93\end{array}$ & $\begin{array}{r}40 \\
22 \\
3 \\
13 \\
10 \\
21 \\
1 \\
1 \\
41 \\
46 \\
41 \\
41 \\
44 \\
39 \\
13 \\
1 \\
17 \\
11 \\
13 \\
26 \\
3 \\
51\end{array}$ & $\begin{array}{l}\text { Green mud. } \\
\text { Green mud, sand. } \\
\text { Shells. } \\
\text { Silt, fine sand. } \\
\text { Shells. } \\
\text { Gray-green mud. } \\
\text { Sand. } \\
\text { Ash. } \\
\text { Gray-green mud. } \\
\text { Green mud. } \\
\text { Do. } \\
\text { Do. } \\
\text { Do. } \\
\text { Do. } \\
\text { Do. } \\
\text { Sand. } \\
\text { Green mud. } \\
\text { Marly sand. } \\
\text { Sandy clay. } \\
\text { Silty sand, shells. } \\
\text { Do. } \\
\text { Green mud. }\end{array}$ \\
\hline
\end{tabular}

1 Samples included in this report.

2 Hydrographic station occupied at this station.

\section{HYDROGRAPHIC STATIONS}

Temperature of water at these stations (fig. 3) shows an abrupt decrease between 50 and 100 meters, and then a slower decrease to less than $2^{\circ} \mathrm{C}$ for the deepest sample $(3,200 \mathrm{~m})$. All $\mathrm{pH}$ determinations (fig. 4) are above 7.5. There is an abrupt decrease at 80 or 100 meters, probably the bottom of the light zone, then a slower decrease to nearly 1,000 meters, then a slow increase. Dissolved oxygen (fig. 5) also shows an abrupt decrease at 80 or 100 meters (base of light zone), and then very low values to about 1,500 meters, then somewhat higher values. Salinity (fig. 6 ) increases sharply between 50 to 70 meters, then falls gradually.

Seasonal variation in temperature and salinity is slight, as indicated by a comparison of figures 3 and 6 with figure 7. Figure 7 shows temperature and salinity data for two stations occupied by the Shuttle expedition in June 1952. Little difference can be seen between the data for June and those for December.

\section{ORGANIC NITROGEN}

Nitrogen analyses were made on the bottom samples taken off the coast of EI Salvador by the micro-Kjeldahl method. Nitrogen values (table 3 ) on the continental shelf range from 0.05 to 0.19 percent. Nitrogen percentage is higher on the slope, reaching the highest values (greater than 0.50 percent) near the oxygen minimum. Below this, values decrease averaging 0.26 percent in the depth range of 1,700 to 3,200 meters. There is little correlation between grain size and nitrogen content of samples. 


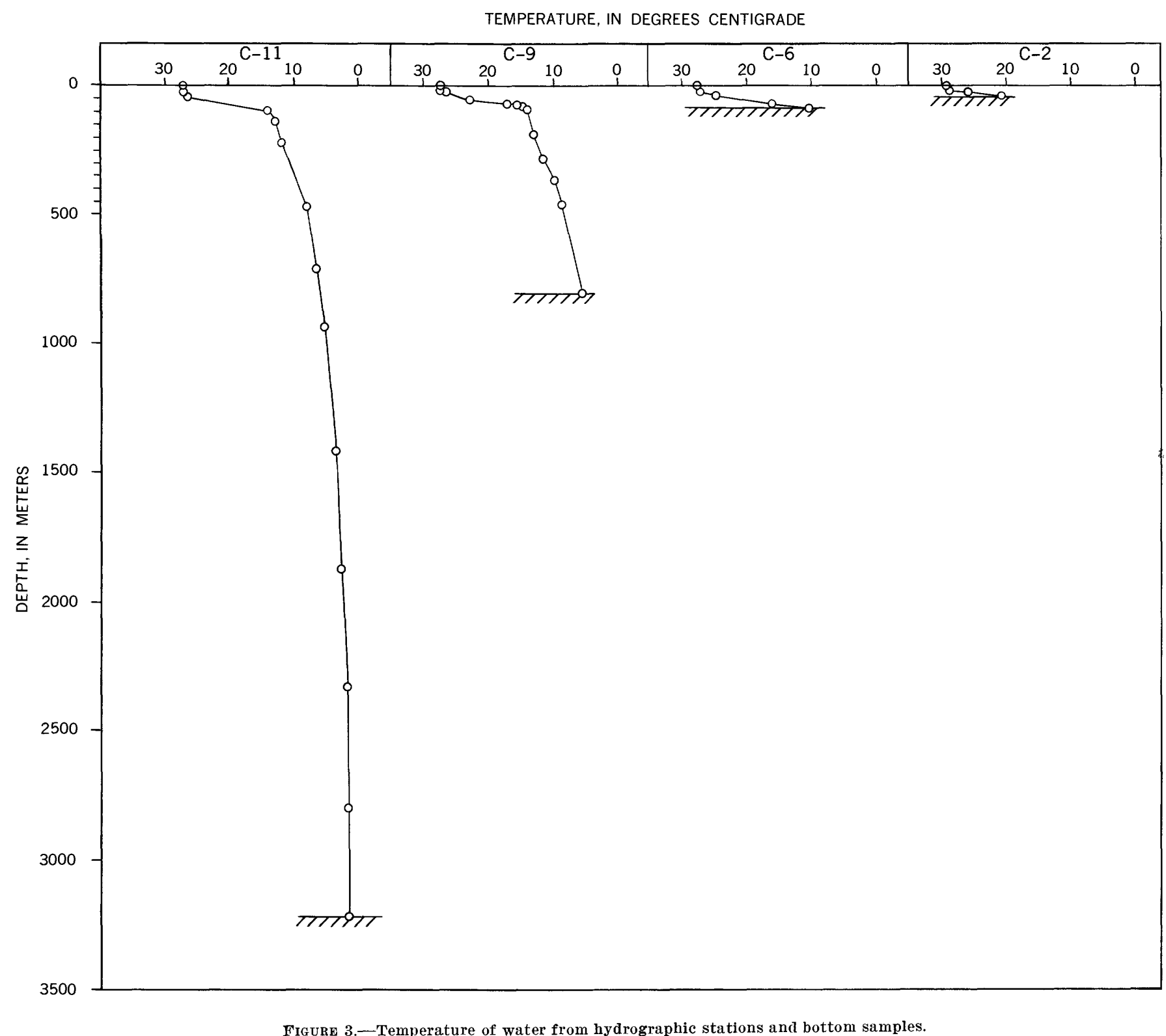

FIgURE 3.-Temperature of water from hydrographic stations and bottom samples. 
QUANTITATIVE AND QUALITATIVE ANALYSIS OF THE FAMILY BOLIVINIDAE

A7

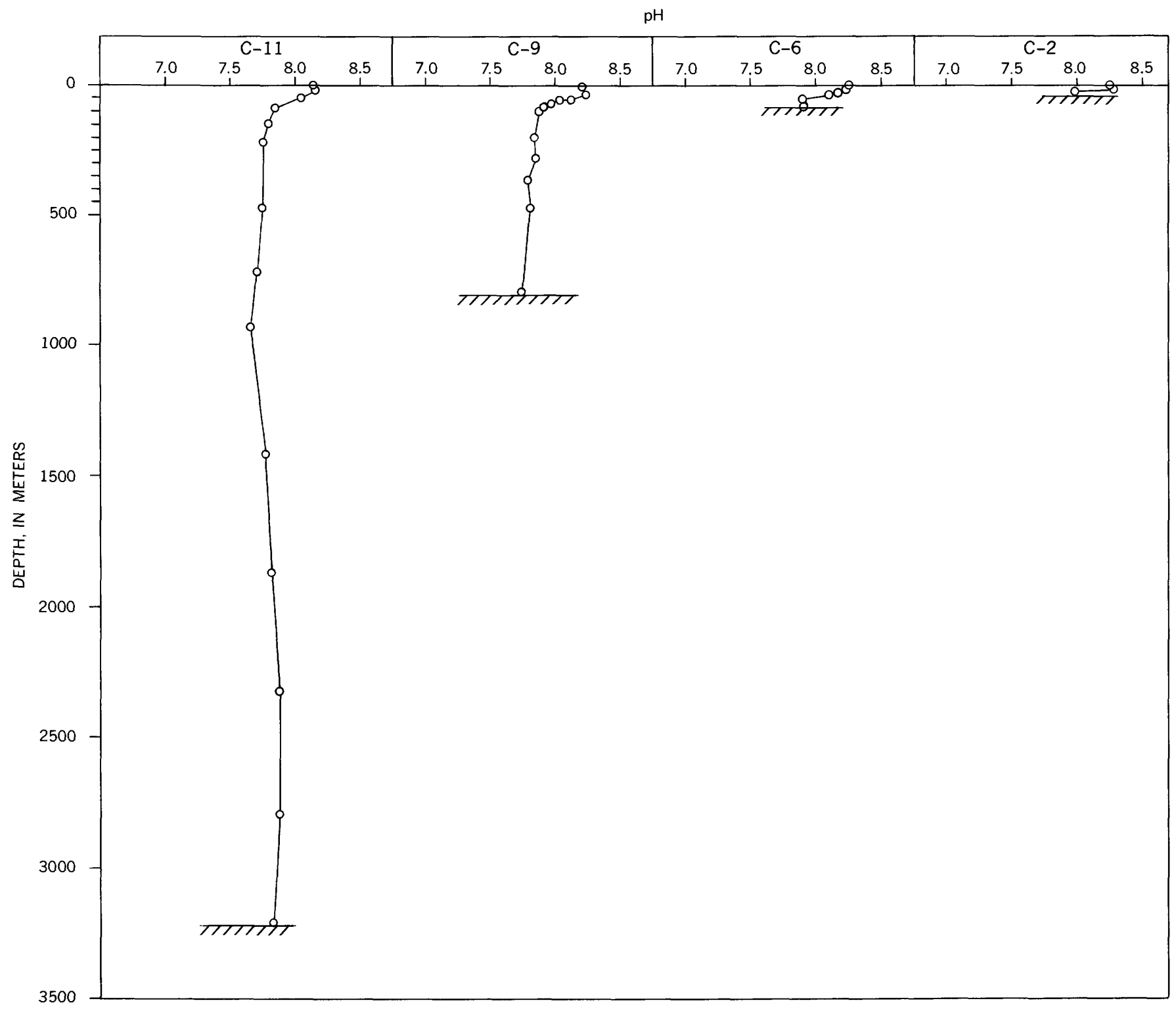

FIGURE 4.-pH of water from hydrographic stations and bottom samples. 


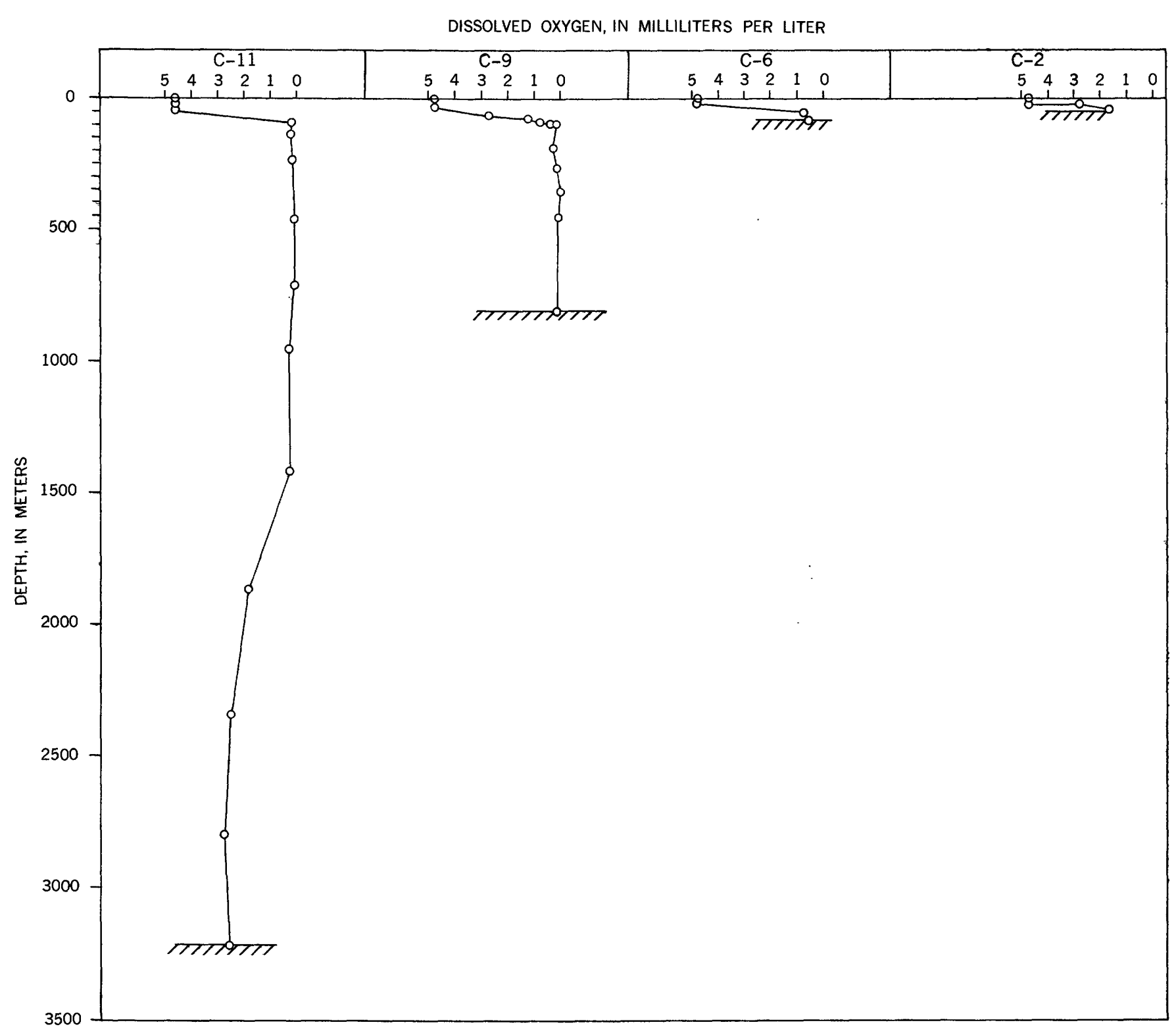

FIGURE 5.-Dissolved oxygen content of water from hydrographic stations and bottom samples. 


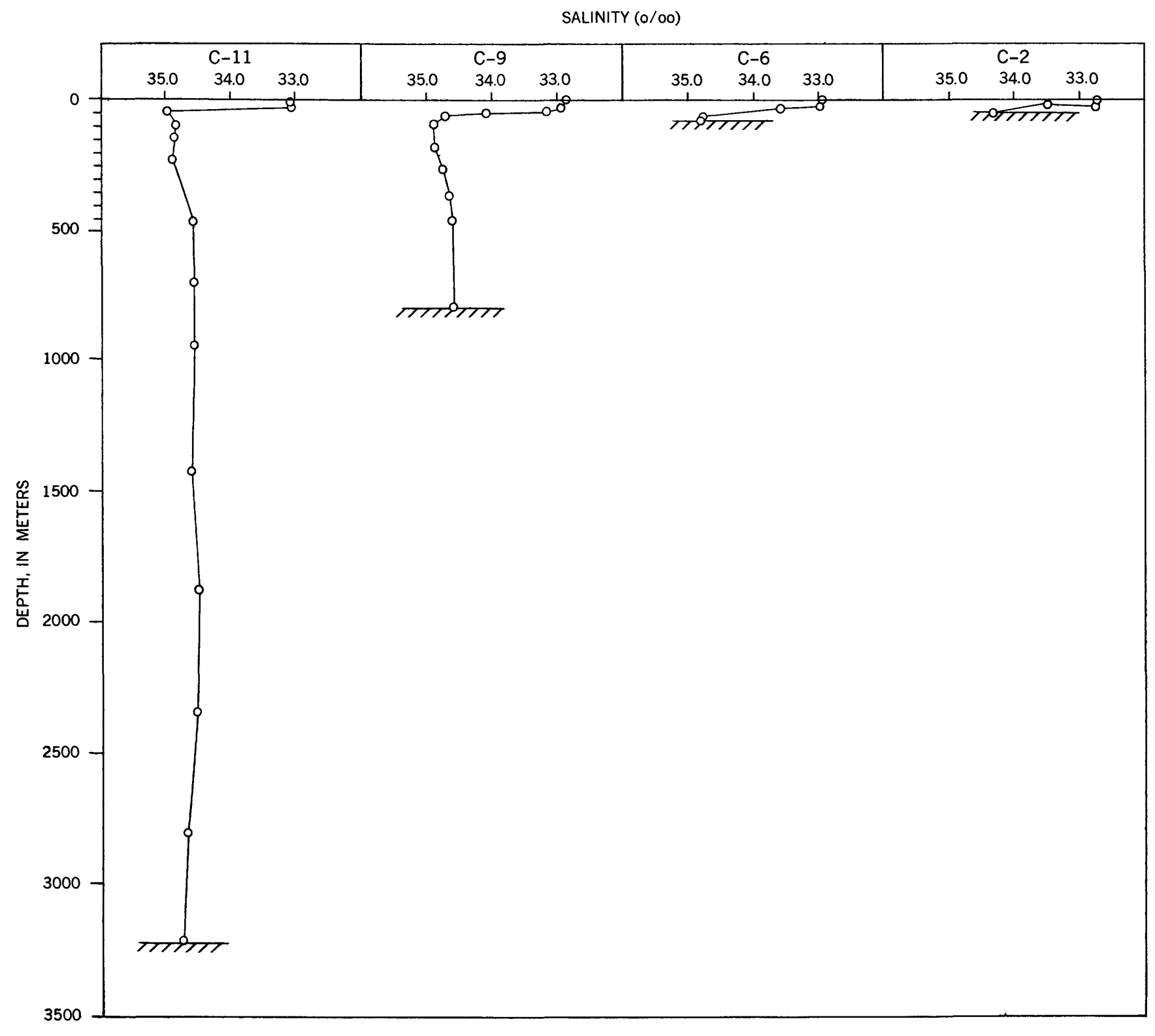

FIgURE 6.-Salinity of water from hydrographic stations and bottom samples. 


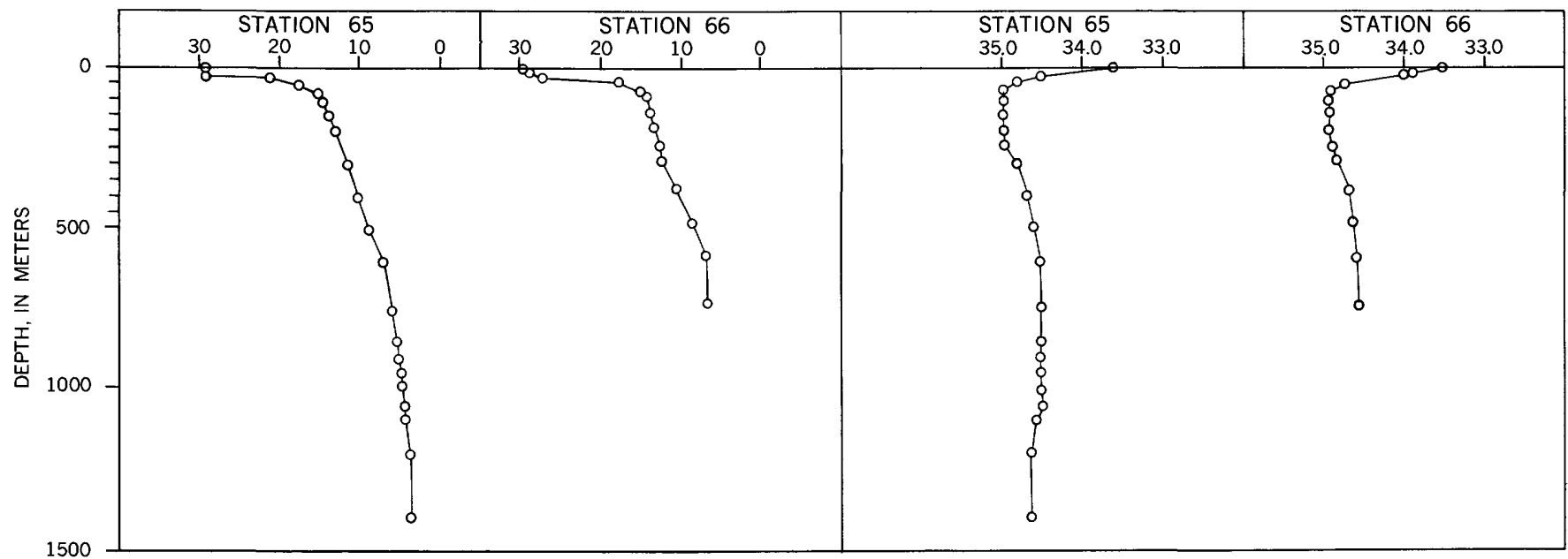

Figure 7.-Hydrographic data from Shuttle expedition, June 1952. For location of samples, see map, Figure 1.

TABLE 3.-Percentage of nitrogen in core samples.

[Data from Hazelton Nuclear Science Corp., Palo Alto, Calif., E. J. Forslow, analyst. Samples marked with (*) are of inadequate size to assure accurate values ]

\begin{tabular}{|c|c|c|c|}
\hline Sample & $\begin{array}{c}\text { Nitrogen } \\
\text { (percent) }\end{array}$ & Sample & $\begin{array}{l}\text { Nitrogen } \\
\text { (percent) }\end{array}$ \\
\hline $\begin{array}{l}\mathrm{C}-2 \\
\mathrm{C}-3 \\
\mathrm{C}-4\end{array}$ & $\begin{array}{r}0.07 \\
.07 \\
.07 \\
.12 \\
* .19 \\
.05 \\
* .24 \\
* .23 \\
.27\end{array}$ & $\begin{array}{l}\mathrm{C}-12 \\
\mathrm{C}-13 \\
\mathrm{C}-15 \\
\mathrm{C}-16 \\
\mathrm{C}-17 \\
\mathrm{C}-18 \\
\mathrm{C}-19 \\
\mathrm{C}-20 \\
\mathrm{C}-22\end{array}$ & $\begin{array}{l}0.28 \\
.51 \\
* 61 \\
.05 \\
* 07 \\
.12 \\
.06 \\
.06 \\
.10\end{array}$ \\
\hline
\end{tabular}

These trends are corroborated by samples taken off the coast of Nicaragua in 1935 by the U.S. Navy ship Hannibal. Analyses of these sediments were made by Roger R. Revelle of the Scripps Institution of Oceanography. These samples were taken between $8^{\circ}$ and $10^{\circ} \mathrm{N}$. latitude, at depths ranging from 10 to 2,300 meters. These nitrogen values (table 4 ) are variable at shallow depths and increase with increasing depth on the continental slope. Maximum values are reached where oxygen values are low, below which nitrogen content decreases.

\section{LABORATORY TECHNIQUE}

In the laboratory, each sample was thoroughly agitated and approximately 10 milliliters (ml) was withdrawn by pipette. This portion was retained in alcohol as a check sample. Rose bengal stain was added to the remainder of the sample, which was allowed to stand for several days (Walton, 1952). It was then washed through a 150-mesh screen (saving fines) and dried and floated in carbon tetrachloride. "Sinks" and "floats" were weighed.

Foraminifera stained with rose bengal (the living forms, see Walton, 1952) were picked from the entire sample and mounted on slides.

Bolivinids were picked from 15 samples; C-2 $(37 \mathrm{~m})$, $\mathrm{C}-20(47 \mathrm{~m}), \mathrm{C}-4(50 \mathrm{~m}), \mathrm{C}-18(64 \mathrm{~m}), \mathrm{C}-6(80 \mathrm{~m})$, $\mathrm{C}-17$ (82 m), C-16 (144 m), C-15 (435 m), C-8 (450 $\mathrm{m}), \mathrm{C}-14(800 \mathrm{~m}), \mathrm{C}-9(885 \mathrm{~m}), \mathrm{C}-13(1,600 \mathrm{~m}), \mathrm{C}-10$ $(1,700 \mathrm{~m}), \mathrm{C}-12(3,100 \mathrm{~m})$, and C-11 $(3,200 \mathrm{~m})$. Samples from depths shallower than 80 meters and deeper than 1,700 meters contained too fow bolivinids for sig-

TABLE 4.-Percentage of nitrogen in core samples taken by the Hannibal expedition in 1935, off the coast of Nicaragua, Central America

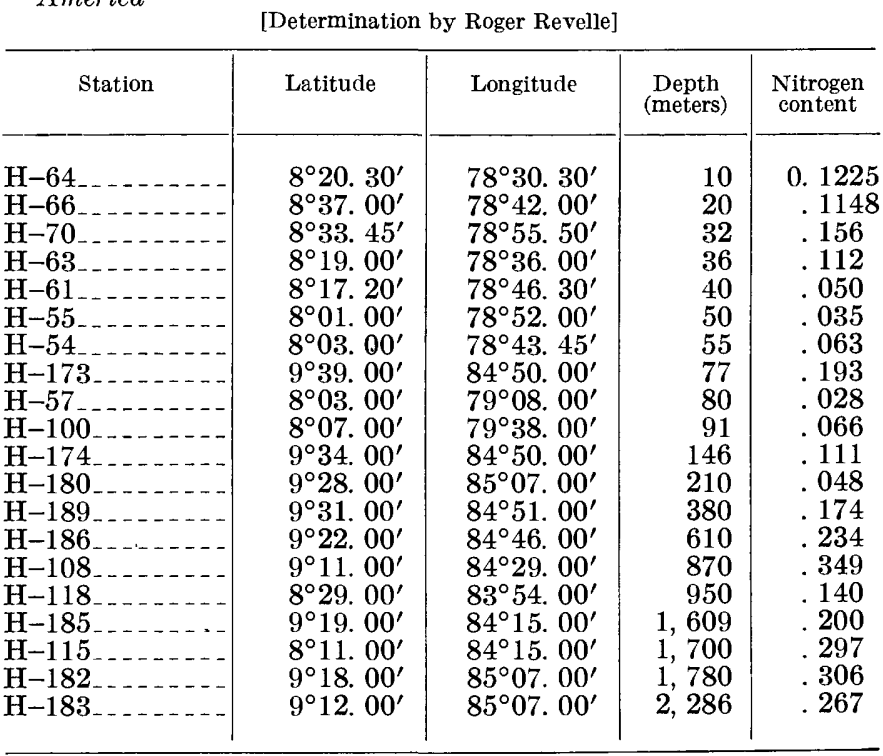


nificant quantitative analysis. Statistical data were compiled for the remaining nine samples $(\mathrm{C}-6, \mathrm{C}-17$, $\mathrm{C}-16, \mathrm{C}-15, \mathrm{C}-8, \mathrm{C}-14, \mathrm{C}-9$, C-13, and $\mathrm{C}-10)$.

For samples C-10, C-13, and C-16, bolivinids were picked from the entire sample. For all other samples, these were picked from a split of the sample which contained about a thousand Foraminifera. Samples were split with a Jones-type microsplitter (Otto, 1933).

Picked specimens of each sample or split, arranged tentatively on the basis of shape and form characters into species, were mounted on a slide. These tentative species were given arbitrary letter designations until their taxonomic affinities were determined by further study.

Species not represented by 80 to 100 individuals from a single split were supplemented (on a second slide) from a split of the remaining sample. Some species are too rare to yield 100 specimens even from the total sample. All perfect specimens from both split and supplement were measured, and statistical parameters were calculated from these measurements.

\section{QUANTITATIVE AND QUALITATIVE ANALYSIS}

The usual first step in analyzing a fauna is to determine what species are present. The definition of a species, however, is a much disputed subject (SylvesterBradley, 1956).

Biologically, species can be defined as $" * * *$ groups of actually (or potentially) interbreeding natural populations which are reproductively isolated from other such groups" (Mayr and others, 1953, p. 25). But even in forms now living it is seldom possible to determine breeding habits, so that in actual practice the biologist must also use morphologic and geographic criteria to define Recent species. He must assume that lack of gradation between forms living together is indicative of inability to interbreed. With unlike forms that do not live together, he can assume that interbreeding ability is improbable. But with groups of similar forms that are isolated from each other, any such assumption is unsafe.

The species definition based only on ability to interbreed leaves out of consideration an appreciable number of lower animals that do not reproduce sexually. Some Foraminifera fall into this category. An understanding of the life cycle is essential in developing a foraminiferal species concept.

In recent years, much interesting work has been done by students of living Foraminifera. Myers (1935 and 1936) described the life cycles of Patellina corrugata and Spirillina vivipara. Le Calvez (1953) described the life cycle of many foraminifers, and explained the cytological changes which occur in such a cycle. Ar- nold $(1953 \mathrm{a}, \mathrm{b} ; 1954 \mathrm{a}, \mathrm{b})$ has studied the great variations in generation after generation of a few foraminiferal species.

Most foraminiferal species whose life cycles have been studied have been found to pass through two biologically differing generations: (a) the sexual generation (gamont) which reproduces by the formation of gametes that unite in pairs to form individuals of (b) the asexual generation (schizont), which in turn reproduces by division of its protoplasm into young schizonts or gamonts. Several asexual generations in succession may occur in some species before a sexual generation is interpolated; in fact, the sexual generation appears to be completely lacking in some species.

The classic concept has related biologic duality with morphologic dimorphism. However, Le Calvez (Arnold, 1956, p. 7) states that the degree of correlation between the two is highly variable, and he feels that the correlation should not be made without biologic evidence.

Many of the species of bolivinids studied here show strong dimorphism; others do not. Even though the life cycle of these forms has not been observed, morphologic dimorphism can probably be correlated with the biologic cycle. Therefore, the absence of dimorphism probably indicates the absence of the sexual generation (oral communication, Zach Arnold, Jan. 18, 1957).

The species problem is complicated by the fact that taxonomic species are never the equivalent of natural species; all the specimens that constitute a natural species can never be observed. However, the larger the sample observed, the closer its parameters will be to those of the entire population. (See "Relation of sample to population," p. A13, this report.) Therefore, the taxonomic species concept should be formed from the largest possible sample. The specimens that make up this sample plus all other specimens included by the author are called the hypodigm of the species (Simpson, 1940). It is with this hypodigm that new specimens should be compared.

The range of variation within a sample may be described quantitatively or qualitatively or both. "Statistical data alone are incapable of recording the morphologic subtleties of the simplest biological form. Conversely, words and pictures alone cannot record the essential group features of a sample" (Imbrie, 1956, p. 220).

To supplement the qualitative "words and pictures," quantitative methods were employed in an attempt to discover the group characteristics and tendencies for the described bolivinids. The results of this analysis form the major part of this paper. 


\section{QUANTITATIVE METHODS}

The purpose of the quantitative analyses of the described forms is twofold: to help define species by quantitatively describing samples (as representatives of populations) and to determine and describe ecologic variations within species.

\section{MEASUREMENTS}

The characteristics measured were selected to meet the requirements both of biologic (or taxonomic) significance and of reproducibility of measurements. (See p. A14.) Measurements were made on specimens mounted firmly on slides, by the use of a micrometer disk in the ocular of the microscope. Length statistics are given in millimeters.

The following measurements and counts were made on every perfect specimen:

1. Maximum length, measured parallel to the long axis; measured to nearest half a micrometer unit.

2. Maximum width perpendicular to long axis; measured to nearest half a micrometer unit.

3. Number of pairs of chambers, excluding proloculus.

4. Diameter of proloculus; measured to nearest half a micrometer unit.

The following measurements were attempted; but as they were not easily reproducible they were not used: 1. Thickness-this, morphologically, is a very important dimension, but it cannot be measured accurately, owing to the difficulty of standing each specimen exactly on edge.

2. Height of last chamber.

3. Angle of suture with periphery.

4. Apical angle.

\section{STATISTICAL CHARACTERIZATIONS}

\section{METHODS AND SIGNIFICANCE}

All species of bolivinids in samples $\mathrm{C}-6, \mathrm{C}-17$, $\mathrm{C}-16, \mathrm{C}-15, \mathrm{C}-8, \mathrm{C}-14, \mathrm{C}-9, \mathrm{C}-13$, and $\mathrm{C}-10$ were measured. Where specimens were abundant enough to make statistical characterization meaningful, the data derived from measurements were plotted in plates 1 to 27 . Plates 1 to 18 represent single species, allowing study of variation with depth. Plates 19 to 27 represent samples, allowing comparison between species. The plates are made up of columns, which are described as follows. For a discussion of the statistical methods used, see Simpson and Roe (1939) and Imbrie (1956).

1. Abundance (column I, pls. 1-27) :

(a) Total number of specimens in split.

(b) Number of perfect specimens in split.

(c) Total abundance in sample (number of specimens in split $\times 2^{x}$, where $x=$ number of splits).
2. Length statistics (column II, pls. 1-27) :

Length statistics were calculated from all measured individuals. These forms apparently continue to grow by adding chambers throughout life, so variation is continuous and there are no clearly marked growth stages. As death probably occurs after reproduction, the length distribution can be described by a more or less normal curve, with the peak of the curve representing the age at which reproductive maturity is most commonly reached.

Statistics were calculated separately for microspheric and megalospheric forms where warranted by abundance and strong dimorphism.

(a) $N$, frequency of measured specimens. (See p. A11, this report.)

(b) $M$, mean length of measured specimens in sample

$$
\left(=\frac{\text { total of lengths }}{N}\right)
$$

(c) $M D$, mean deviation of length

$$
\text { (= }=\frac{\text { total of deviations from mean length }}{N} \text { ). }
$$

(d) $\sigma$, standard deviation, a parameter of the normal curve

$$
\left[=\left(\frac{\text { total of (deviations })^{2}}{N}\right)^{\frac{1}{2}}\right] \text {. }
$$

(e) $V$, coefficient of variability, a pure number for comparison of variability between species of different size

$$
\left(=\frac{100 \sigma}{M}\right)
$$

(f) Range; O.R., observed range, or range in sample; S.R., standard range, or range in hypothetical population $(=M-3 \sigma$ to $M+3 \sigma$ (p. A13, this report)).

(g) Length frequency histogram (column IIb). Living specimens are shown as $X$ in this diagram.

3. Growth characteristics: Comparison of such form characters as number of chambers, width, and flare add to knowledge of manner and direction of growth in some species. Columns III to $\mathrm{V}$ of plates 1-27 are scatter diagrams of measurements of these characters versus length. These bivariate diagrams show more or less scatter along a straight or curved line called the growth line. The amount of scatter is an indication of the amount of variability found in the species. As pointed out by Imbrie $(1956$, p. 228$), “ * * *$ the growth line of a bivariate population is analogous to the mean of a normal univariate population in 
that both represent a morphological norm around which observed values tend to cluster. One represents the average value actually attained by a given growth stage; the other, the average path by which the adult form was attained."

Living specimens (p. A14, this report) are shown as $X$ on these diagrams.

(a) Number of chambers (column III, pls. 1-27): The number of pairs of chambers of each individual is plotted against its length. Two sizes of dots were used to indicate microspheric or megalospheric proloculus.

The diagram reveals the presence or absence of dimorphism. Most species show a marked dimorphism both by number of pairs of chambers per unit length and by proloculus diameter. Some species are not dimorphic; these usually have small variable proloculus diameters.

The diagrams also show approximately the increase in height of the chambers relative to increasing length. Assuming that within a species the number of chambers is a rough indication of age, comparison of length in different samples at the 5 or 10 chamber stage will indicate relative rate of growth. Bradshaw (1957) found in laboratory experiments on Streblus beccarii var. tepida that, for that form, the rate of addition of chambers was strongly influenced by temperature and salinity changes. However, within the depth range of these Recent Bolivinas, particularly those from great depths, there is very little variation in temperature and salinity.

(b) Width (column IV, pls. 1-27): The width of each specimen is plotted against its length. From this diagram, the growth index (length to width ratio) of each specimen can be calculated. For species which showed great scatter on this diagram, microspheric and megalospheric individuals are distinguished by two sizes of dots.

(c) Flare (column V, pls. 1-27) : The growth index (length to width ratio) of each specimen is plotted against its length; the angle made with the horizontal by the trend of these points indicates the amount of flare of the species. Rapidly flaring forms show little increase in growth index with increase in length, hence the trend shows a low angle with the horizontal. Parallel-sided forms have a great increase in growth index beyond the early part of the test, and the angle of the trend is higher.

The principal advantage of the diagram is that the trend of points is fairly well represented by a straight line. The line computed to represent this trend is the reduced major axis (Imbrie, 1956, p. 230-233). The angle this axis makes with the horizontal varies inversely with the amount of flare, and is very useful in comparison within and between species.

Computation of this axis is as follows, using the formula for a straight line, $y=a x+b$, where $x=$ length, and $y=\frac{\text { length }}{\text { width }}$.

$$
\begin{array}{rlrl}
a=\frac{\sigma_{y}}{\sigma_{x}} & \quad a & =\text { growth ratio } \\
b=M_{y}-a M_{x} & b & =\text { initial growth index } \\
M_{y} & =\text { mean of } y \\
M_{x} & =\text { mean of } x \\
& & \sigma_{y} & =\text { standard deviation of } y \\
\sigma_{x} & =\text { standard deviation of } x
\end{array}
$$

Where scatter was great, two sizes of dots were used to determine whether dimorphism is reflected in flare.

\section{RELATION OF SAMPLE TO POPULATION}

Ideally, a sample is a group of individuals withdrawn from a population by a method that will produce an unbiased sample (Simpson and Roe, 1939, p. 166-185). In this paper, each sample collected (for example, C-9, C-14) can be considered a random sample chosen from a population which includes all the foraminifers present on the sea bottom in that ecologic area. (See p. A27.) From each of these samples, a smaller sample was drawn (by the use of a microsplitter) which is considered to represent the original sample, and hence the population. The parameters calculated for this sample will more or less approximate the parameters of the population.

Statistical methods are used to relate the sample to the population. These methods assume distributions that can be expressed by the normal curve-the bellshaped curve representing the most probable distribution of a variate (Simpson and Roe, 1939, p. 149-158). The character of this normal curve is such that values are equally distributed on each side of the mean, 68 percent lying within $\sigma$ of the mean, 96 percent lying within $2 \sigma$ of the mean, and almost 100 percent lying within $3 \sigma$ of the mean. Therefore, the length range of the hypothetical population is considered to be $\mathrm{M}-3 \sigma$ to $\mathrm{M}+3 \sigma$. This standard range is almost always larger than the observed range if distribution is normal. 
The mean, the standard deviation, and the coefficient of variability of the length of the sample are related to population parameters by means. of the standard error of the sample parameters. These sample parameters themselves are usually normally distributed. If a number of separate samples of the same size were drawn from a population and their mean lengths calculated, a frequency distribution of the mean length would be described by a normal curve. For example, the standard deviation of the mean $\left(\sigma_{M}\right)$ is called its standard error, and has the same relation to the mean length as the standard deviation of the length has to the length; that is, it is probable that the real value of the mean will be within the range of $3 \sigma$ on either side of the observed value. Values of the standard errors are inversely proportional to the square root of the frequence of variates

$$
\left(\sigma_{M}=\frac{\sigma}{\sqrt{N}}, \sigma_{\sigma}=\frac{\sigma}{\sqrt{2 N}}, \sigma_{V}=\frac{V}{\sqrt{2 N}}\right) .
$$

The standard errors are therefore a measure of the reliability of the measured sample parameters. The standard error of the mean, standard deviation, and coefficient of variability are given in column IIa of plates 1-27.

To determine how significant the length statistics are, a normal curve for each frequency histogram is shown in column IIb, plates 1-27. The more closely the sample distribution corresponds to the normal curve, the more meaningful will be the calculated population parameters.

\section{LIVING SPECIMENS}

Specimens stained with rose bengal were measured and are plotted on the diagrams as $\mathbf{x}$. They were very abundant in several samples, and for such samples the length statistics and frequency distribution are plotted separately. In all cases where such living specimens occur, their distribution closely conforms to that of the dead specimens in the sample.

\section{REPRODUCIBILITY OF QUANTITATIVE DATA}

In order to determine the reliability of the data, tests were made to determine reproducibility of (a) measured samples, (b) measurements, and (c) calculations.

\section{MEASURED SAMPLES}

For samples C-6 and C-14, statistical parameters were calculated separately for specimens in the original split and for the split plus supplement. In every case, variation of all parameters between the two "samples" was within the standard error of the parameter.

\section{MEASUREMENTS}

A. O. Woodfard repeated measurements made by the author on one sample of Bolivina semiperforata.
Most of the duplicate measurements were identical with the original measurements or varied from them by only half a micrometer unit; a few varied by 1 unit $(0.017$ $\mathrm{mm}$ ) or more. Statistics calculated in micrometer units from the two sets of data agreed to the second decimal place. A more thorough test of reproducibility could have been obtained if specimens could have been unglued and remounted before being remeasured, but many specimens are too fragile to withstand this treatment.

\section{Calculations}

All calculations were made and checked by the author on a calculator. For several species, tabulation and calculations were rechecked by A. O. Woodford. This check revealed that in one sample a specimen had been accidentally omitted from the tabulation and calculations, but because of the large number of specimens this omission produced no differences in the statistics.

\section{SYSTEMATIC DESCRIPTIONS}

Eighteen species of the family Bolivinidae are herein qualitatively and quantitatively described. Included are 17 species of the genus Botivina and 1 of Suggrumda.

All species (except $B$. inflatta Heron-Allen and Earland) were compared by the author with primary types at the U.S. National Museum and the University of Southern California, as were all forms noted in the synonymies.

Holotypes and illustrated specimens are deposited in the U.S. National Museum, Washington, D.C.

\section{Family BOLIVINIDAE}

\section{Genus BOLIVIN A d'Orbigny, 1839}

Type species.-Bolivina plicata d'Orbigny. Test elongate, compressed, chambers biserially arranged, in some forms tending to become uniserial in later part of test; edges of test rounded, subangular, carinate, or spinose; wall smooth or ornamented; aperture an elongate slit extending from the basal suture into the apertural face, in some forms tending to become terminal and oval; aperture occasionally with a thin lip and platelike tooth.

The genus Bolivina as here defined includes the genus Loxostomum Ehrenberg. The latter genus was defined by Cushman (1948, p. 269) as tending to become uniserial in the later stages, with an aperture tending to become terminal and oval. Two forms present in these samples ( $B$. pseudobeyrichi and $B$. bradyi) have been referred to the genus Loxostomum by several authors. Of the thousands of specimens of these 2 species examined from this area, only 1 specimen of $B$. pseudobeyrich $i$ was found which was definitely uniserial. All 
others were biserial throughout their length. These two species have apertures closed at the base, although they are not terminal: they are evidently intermediate between Bolivina and Loxostomum. Because no clearcut distinction can be made between Bolivina and Loxostomum, the two are included as subgenera of the genus Bolivina.

\section{Subgenus BoLIVINA s. s.}

Type species.-Bolivina plicata d'Orbigny. Test elongate, compressed, chambers biserially arranged; aperture an elongate slit extending from the basal suture into the apertural face, occasionally with a thin lip and platelike tooth.

\section{Bolivina (Bolivina) seminuda Cushman}

Plate 29, figures 1-7

Bolivina seminuda Cushman, 1911, U.S. Natl. Mus. Bull. 71, pt. 2, p. 34, fig. 55 .

Cushman, 1927, Scripps Inst. Oceanography Bull., Tech ser., v. 1, no. 10, p. 157, pl. 3, fig. 6 .

Cushman, 1937, Cushman Lab. Foram. Research, Spec. Pub. 9, p. 142, pl. 18, fig. 14 [not figs. 13, 15].

Cushman and McCulloch, 1942, Allen Hancock Pacific Expedition Repts., v. 6, no. 4, p. 210, pl. 25, fig. 14 .

Bandy and Arnal, 1957, Am. Assoc. Petroleum Geologists Bull., v. 41, p. 2050.

Bolivina seminuda Cushman var. foraminata R. E. and K. C. Stewart, 1930, Jour. Paleontology, v. 4, p. 66, pl. 8, figs. $5 \mathrm{a}, \mathrm{b}$.

Bolivina foraminata R. E. and K. C. Stewart. Coryell and Mossman, 1942, Jour. Paleontology, v. 16, p. 239, 241, pl. 36, fig. 34 .

[not] Bolivina seminuda Cushman, 1942, U.S. Natl. Mus. Bull. 161, pt. 3, p. 26, pl. 7, fig. 6 .

Test large, subcylindrical, tapering evenly from acute initial end in microspheric form, and rounded initial end in megalospheric form; periphery broadly rounded, nearly smooth; chambers numerous, only slightly if at all inflated, increasing evenly in height as added; diameter of proloculus less than $0.017 \mathrm{~mm}$. in microspheric, to as much as $0.085 \mathrm{~mm}$. in megalospheric form; sutures only slightly depressed, straight, very slightly oblique to periphery; all or later part of test with upper part of chambers clear and imperforate, lower part coarsely perforate; early part of test occasionally ornamented with thin discontinuous costae; aperture long, narrow, loop shaped, with lip.

QUANTITATIVE DATA (PL. 1)

Observed depth range. -435 to 3,200 meters.

Abundance (I).-Abundant in samples C-15, C-8, $\mathrm{C}-14$, C-9, rare in $\mathrm{C}-10$. Very rare in $\mathrm{C}-13(1,600$ $\mathrm{m})$ and $\mathrm{C}-11(3,200 \mathrm{~m})$.
Length (II).-Distribution close to normal curve, curve relatively flat; standard range (S. R.) close to observed range (O. R.) ; mean deviation $(M D)$ and standard deviation $(\sigma)$ low; variability $(V)$ low to moderate. Length distribution and statistics of microspheric and of megalospheric forms similar. Statistics very similar for samples from same depth $(\mathrm{C}-15$ very similar to C-8, C-14 very similar to C-9); total abundance, length range, and mean larger in samples $\mathrm{C}-14$ and $\mathrm{C}-9$ than in shallower or deeper samples.

Number of chambers (III).--Strong dimorphism shown by number of chambers and by proloculus diameter. Megalospheric specimens slightly more abundant than microspheric in all samples. Specimens in C-14 and C-9 with higher chambers than those in C-15 and $\mathrm{C}-8$ at the same growth stage. Smallest number of chambers measured: microspheric form, 7 pairs; megalospheric form, 2 pairs.

Width (IV).-Width increasing uniformly but not. rapidly with length; scatter slight. Megalospheric forms slightly wider than microspheric forms in early part (not shown on diagram because of tight clustering of points). Specimens reach greater width in C-14 and $\mathrm{C}-9$ than in other samples.

Flare (V).-As shown by lower slope angles, specimens in $\mathrm{C}-14$ and $\mathrm{C}-9$ more flaring than those in $\mathrm{C}-15$ and $\mathrm{C}-8$.

Living specimens.-Abundant in C-15; mean length and length distribution very similar to corresponding values for dead specimens. Distribution of living specimens in other samples close to that of dead ones. DIAGNOSTIC FEATURES

The most characteristic features of this species are its large size, very round periphery, nearly horizontal sutures, and the clear imperforate areas on all or some of its chambers. Much variation is present in number of chambers showing clear areas. Many specimens have these imperforate areas present on all chambers, as in the typical form (pl. 29, figs. 6, 7) ; many have clear areas only on the last pair of chambers, and are identical with $B$. seminuda var. foraminata R. E. and K. C. Stewart (pl. 29, figs. 1-5). This variation occurs within each sample, so is not of subspecific importance; therefore the Stewarts' form is included in the synonymy of $B$. seminuda. Although the two forms occur together, specimens with clear areas on all chambers greatly outnumber the foraminata-type specimens in samples $\mathrm{C}-15$ and $\mathrm{C}-8$, while in samples $\mathrm{C}-14$ and $\mathrm{C}-9$, the former type is much rarer than the latter.

Botivina seminuda is strongly dimorphic, with the megalospheric form having a much larger proloculus and many fewer chambers than the microspheric form. 
The length distribution for both the microspheric and megalospheric forms is close to normal. Within each sample, little variability is shown in length versus width or versus flare.

The species varies strongly in size with change in depth. The specimens in samples from 800 to 885 meters show greater length, width, and flare than specimens from other samples.

\section{Bolivina (Bolivina) humilis Cushman and McCulloch}

Plate 29, figures 10-13

Bolivina seminuda Cushman var. humilis Cushman and McCulloch, 1942, Allen Hancock Pacific Expedition, Repts., v. 6, no. 4, p. 211, pl. 26, figs. 1-6.

Bandy and Arnal, 1957, Am. Assoc. Petroleum Geologists Bull., v. 41, p. 2050.

Test small, oval in cross section, tapering in first part, then nearly parallel sided; periphery broadly rounded to subacute; chambers low, slightly inflated, more numerous in microspheric than in megalospheric form; sutures nearly straight to slightly lobed, horizontal or slightly oblique, depressed, limbate; proloculus diameter in microspheric form less than 0.017 $\mathrm{mm}$, in megalospheric form $0.05 \pm \mathrm{mm}$; wall perforate in lower part of chambers, clear in upper part; aperture loop shaped with lip.

QUANTITATIVE DATA (P1., 2)

Observed depth range.-144 to 1,700 meters.

Abundance (I).-Highest in C-8, rare in C-10, very rare in $\mathrm{C}-16$ (144 m).

Length (II).-Distribution very close to normal curve; standard range (S. R.) close to observed range (O. R.) ; mean deviation ( $M D$ ) and standard deviation $(\sigma)$ small; variability $(V)$ low to moderate. Statistics similar for samples $\mathrm{C}-\mathbf{1 5}$ and $\mathrm{C}-8$. Little variation in length range and mean throughout depth range.

Number of chambers (III).-Dimorphism shown by number of chambers and by proloculus diameter. Microspheric and megalospheric specimens approximately equal in number. Chambers of nearly equal height in all samples. Smallest number of chambers observed: microspheric form, 8 pairs; megalospheric form, 4 pairs.

Width (IV).-Little increase in width with length after early part. Little scatter; no difference in trend between microspheric and megalospheric forms.

Flare (V).--Little variation in flare throughout depth range; angle of slope high, indicating parallelsided form.

Living specimens. - None found in any sample.
DIAGNOSTIO FEATURES

The test is small, the later part nearly parallel sided, and the periphery is rounded. The sutures are limbate and curved; the chambers are low.

The species is dimorphic, with moderate difference in proloculus diameter between megalospheric and microspheric forms, also a slight difference in number of chambers. Little variation is shown within samples, scatter diagrams show tight clustering of points. There is little variation in the size of the species throughout its depth range, which is great.

This form closely resembles Cushman and McCulloch's specimens. As it occurs in the same samples as $B$. seminuda s. s. and as there is no evidence of intergradation between the two forms, $B$. humilis is raised to specific rank.

\section{Bolivina (Bolivina) paciflca Cushman and McCulloch}

Plate 29, figures 8,9

Bolivina seminuda Cushman, [part], 1937, Cushman Lab. Foram. Research Spec. Pub. 9, pl. 18, fig. 15 [not figs. 13, 14].

Bolivina acerosa Cushman var. pacifica Cushman and McCulloch, 1942, Allen Hancock Pacific Expedition, Repts., $\mathbf{r}$. 6 , no. 4, p. 185-186, pl. 21, figs. 2 , 3.

Test small, slender, compressed; tapering from subacute initial end; periphery rounded, nearly smooth or slightly lobulate; chambers slightly inflated, increasing evenly in size as added; sutures depressed, nearly straight, oblique to periphery; upper part of chambers clear and hyaline, lower part finely perforate, with milky appearance; no dimorphism in number of chambers, no strong dimorphism in proloculus size; aperture loop shaped, from base of apertural face to apex.

QUANTITATIVE DATA (PL. 3)

Observed depth range. -50 to 3,100 meters.

Abundance (I).-Abundant in $\mathrm{C}-6, \mathrm{C}-17$, rare in $\mathrm{C}-16$ and $\mathrm{C}-10$, very rare in $\mathrm{C}-4(50 \mathrm{~m})$.

Length (II).-Distribution extremely close to normal curve; standard range (S. R.) very close to observed range (O.R.) ; mean deviation $(M D)$ and standard deviation $(\sigma)$ small; variability $(V)$ low. Mean length similar in all samples but decreasing very slightly with increasing depth.

Number of chambers (III).-Slight dimorphism shown by proloculus diameter in samples $\mathrm{C}-8, \mathrm{C}-14$, and $\mathrm{C}-13$, but not in $\mathrm{C}-6$ or $\mathrm{C}-17$, where specimens are most abundant; this may indicate a variability of proloculus diameter rather than true dimorphism, as no dimorphism is apparent in number of chambers. Chambers very slightly higher in $\mathrm{C}-6$, and $\mathrm{C}-17$ than in 
deeper samples. Smallest number of chambers observed, four pairs.

Width (IV).-Specimens increasing little in width after early part of test; amount of scatter small.

Flare (V).-Angle of slope high, nearly equal in all samples; amount of scatter fairly large.

Living specimens.-Distribution similar to that of dead specimens.

\section{DIAGNOSTIO FEATURES}

The test is small and very slender. The sutures are oblique, curved, and depressed. The upper part of the chambers is clear and imperforate. Dimorphism is absent or very weak. The proloculus diameter is variable. Length, width, and flare vary little throughout the very great depth range.

Bolivina pacifica is variable in amount of chamber inflation. It somewhat resembles $B$. translucens $\mathrm{Phle-}$ ger and Parker (1951, pt. 2, p. 15, pl. 7, figs. 13, 14) but has more oblique sutures. It differs from $B$. seminuda Cushman (pp. A15, A16, this report) in its oblique and depressed sutures, smaller size, and more inflated chambers. It occurs in the same samples as $B$. seminuda, but there is no intergradation between the two forms. B. acerosa Cushman (Cushman Lab. Foram. Research Spec. Pub. 6, p. 54, pl. 8, fig. 1, 1936) is much narrower and has more curving sutures.

\section{Bolivina (Bolivina) argentea Cushman}

Plate 29, figures 14-17

Bolivina argentea Cushman, 1926, Cushman Lab. Foram. Research., Contr., v. 2 , pt. 2 , p. 42 , pl. 6 , fig. 5 .

Cushman, 1937, Cushman Lab. Foram. Research Spec. Pub. 9 , p. 140, pl. 19, figs. 7-11.

Bandy and Arnal, 1957, Am. Assoc. Petroleum Geologists Bull., v. 41, p. 2050.

?Bolivina dottiana Coryell and Mossman, 1942, Jour. Paleontology, v. 16, p. 239, pl. 36, fig. 33.

Test large, flat, periphery subacute to keeled, tapering to a rounded but spined initial end in megalospheric form, and to an acute, often spined initial end in microspheric form; microspheric form with numerous chambers, proloculus diameter less than $0.017 \mathrm{~mm}$; megalospheric form with fewer chambers, proloculus diameter 0.068-0.11 $\mathrm{mm}$; sutures wide, curved, oblique to periphery, limbate, and very white; wall finely perforate, silvery; test with two strong costae on early part; aperture loop shaped, with well-developed internal tooth.

\section{QUANTITATIVE DATA (PL. 4)}

Observed depth range.-800 to 1,700 meters.

Abundance (I).-Abundant in C-9 and C-14, very rare in $\mathrm{C}-10(1,700 \mathrm{~m})$.

Length (II).-Distribution skewed to left, owing to presence of very large individuals, unlike normal curve; mean deviation $(M D)$ and standard deviation $(\sigma)$ large; variability $(V)$ great. Distribution of miscrospheric individuals very similar to that of megalospheric individuals. Statistics and distribution for the two samples similar.

Number of chambers (III).-Strong dimorphism shown both by number of chambers and by proloculus diameter. Megalospheric individuals several times more abundant than microspheric individuals. Smallest number of chambers observed: microspheric form, 8 pairs; megalospheric form, 1 pair.

Width (IV).-Width increasing rapidly with length, at fairly uniform rate; dimorphism reflected in length to width ratio (microspheric form tapers more rapidly than megalospheric).

Flare (V).-Form tapering rapidly; about equally flaring in two samples. Megalospheric specimens more flaring than microspheric at low length, about equal later.

\section{Living specimens.-None found.}

diagNostio FEATURES

This species is large and flat, and the periphery is smooth, with a narrow keel. Sutures are broadly limbate. The wall has a silvery opalescent appearance not found in any other species in these samples.

It is strongly dimorphic, with the megalospheric proloculus diameter very large, and with many more chambers in the microspheric form than in the megalospheric.

The depth range is restricted.

The holotype and paratypes of this species, from Lydonia Station 30, are less flaring and have more inflated chambers than have the specimens in $\mathrm{C}-14$ and C-9. These types show low costae which in some forms run the entire length of the test. Specimens from off the coast of California, illustrated in Cushman Laboratory Special Publication no. 9, are identical with those from off El Salvador.

Bolivina dottiana Coryell and Mossman is only questionably included in the synonymy as types are not available for comparison.

\section{Bolivina (Bolivina) interjuncta bicostata Cushman}

\section{Plate 30, figures 1-4}

Bolivina costata d'Orbigny var. bicostata Cushman, 1926, Cushman Lab. Foram. Research, Contr., v. 2, pt. 2, p. 42. Bandy and Arnal, 1957, Am. Assoc. Petroleum Geologists Bull., v. 41, 1. 2050.

Bolivina interjuncta Cushman var. bicostata Cushman, 1939, Cushman Lab. Foram. Research Spec. Pub. 9, p. 116, pl. 22, fig. 23.

Cushman and McCulloch, 1942, Allen Hancock Pacific Expedition, Repts., v. 6 , no. 4, p. 195, pl. 23, figs. 9-11, 13-16.

Bolivina interjuncta Cushman. Natland, 1950, Geol. Soc. America Mem. 43, pt. 4, p. 20-21, pl. 5, fig. 16. 
Test large, compressed, rapidly tapering; periphery subacute, keeled; chambers slightly inflated, more numerous in microspheric than in megalospheric form; strong dimorphism in proloculus diameter; sutures limbate, raised, in later part of test often higher than costae, broad, curved, oblique; wall finely perforate; test ornamented with strong sharp costae over most of length, the two median costae stronger than the others; aperture large, loop shaped, with well-developed internal tooth.

QUANTITATIVE DATA (PL. 5)

Observed depth range. -80 to 800 meters.

Abundance (I).--Abundant in C-6, C-17, C-8, very rare in $\mathrm{C}-14(800 \mathrm{~m})$.

Length (II).-Distribution fairly close to normal curve, curve flat, bimodal in $\mathrm{C}-17$; standard range (S. R.) larger than observed range (O.R.) ; variability (V) moderate. Length distribution and statistics similar for all samples throughout depth range.

Number of chambers (III).--Strong dimorphism shown by proloculus diameter and number of chambers. Few microspheric specimens in C-6, but many in C-8; length range of microspheric specimens in C-8 greater than that of megalospheric. Chambers about equal in height in all samples. Smallest number of chambers observed: microspheric form, 9 pairs; megalospheric form, 2 pairs.

Width (IV).-Width increasing rapidly with length. Dimorphism not shown.

Flare (V).--Species about equally flaring throughout depth range, taper moderate. Microspheric specimens more flaring than megalospheric.

Living specimens.-Only a few specimens found.

DIAGNOSTIO FEATURES

This is a large species, characterized by four sharp glassy costae over most of its length. The sutures are glassy and raised.

The species is dimorphic, but the microspheric proloculus is larger than in most species. The size (length range and mean and flare) is nearly the same throughout the depth range.

The form differs from $B$. interjuncta Cushman (1926, p. 41, pl. 6, fig. 3) in lacking anastomosing costae. The geographic and geologic relations of the two forms were not ascertained; so subspecific status is retained.

Natland $(1950$, p. 20$)$ states that in samples from deep water it is difficult to distinguish this form from $B$. argentea Cushman. In these samples, though $B$. argentea does have costae (p. A17), it can readily be distinguished from $B$. interjuncta bicostata by its silvery appearance, much thinner test, wider unraised sutures, and also by its strong dimorphism.

\section{Bolivina (Bolivina) semiperforata Lewis Martin}

Plate 30, figures $5-8$

Bolivina semiperforata Lewis Martin, 1952, Cushman Found. Foram. Research Contr., v. 3, p. 129, pl. 21, figs. 10, 11.

Bolivina spissa Cushman. Crouch, 1952, Am. Assoc. Petroleum Geologists Bull., v. 36, p. 830, pl. 3, fig. 7 .

Bandy and Arnal, 1957, Am. Assoc. Petroleum Geologists Bull., v. 41, p. 2050.

Test slender, tapering, oval in cross section, commonly with apical spine; periphery acute and commonly keeled in early part of test, subacute or rounded in later part; periphery smooth, that of last chamber lobed; chambers low, very slightly inflated, numerous in microspheric form, fewer in megalospheric; sutures broad, depressed, curved, opaque, oblique to periphery, and very white; wall thin, perforate, except for clear hyaline patches at inner end of chamber; proloculus diameter less than $0.017 \mathrm{~mm}$ in microspheric form, $0.05-0.10 \mathrm{~mm}$ in megalospheric form; early part of test ornamented with several thin costae; aperture loop shaped with slight lip.

QUantitative Data (PL. 6)

Observed depth range. -800 to 1,700 meters.

Abundance (I).-Abundant in C-9, C-14, rare in $\mathrm{C}-13$ and $\mathrm{C}-10$.

Length (II).-Distribution close to normal curve; observed range (O.R.) close to standard range (S.R.) ; variability $(V)$ low except for C-13, a small sample. Mean length of microspheric forms higher than that of megalospheric, $V$ higher for microspheric than megalospheric. Statistics very similar for samples $\mathrm{C}-14(800 \mathrm{~m})$ and $\mathrm{C}-9(885 \mathrm{~m})$; species rare in C-13 $(1,600 \mathrm{~m})$ and $\mathrm{C}-10(1,700 \mathrm{~m})$, so statistics not so significant.

Number of chambers (III).-Strong dimorphism shown by proloculus diameter and by number of chambers. Megalospheric forms about twice as abundant as microspheric in all samples. Chambers nearly equal in height in all samples. Smallest number of chambers observed: microspheric form, 7 pairs; megalospheric form, 4 pairs.

Width (IV).-Width increasing uniformly with length, scatter tight. Dimorphism not reflected in width.

Flare (V).-Scatter large, variation in taper great. Species about equally flaring in all samples.

Living specimens.-Present only in C-9. Distribution conforms to that of dead specimens.

DIAGNOSTIC FEATURES

The test is slender and oval in cross section. The periphery is subacute, the sutures curved, wide, and white. An apical spine is usually present. 
The species is strongly dimorphic, the megalospheric form having a large proloculus. The microspheric form has many more chambers than the megalospheric.

There is little variation in size throughout the depth range of the species.

Botivina semiperforata differs from $B$. ordinaria Phleger and Parker (Cushman Found. Foram. Research, Contr., v. 3, p. 14, 1952) by having depressed sutures, clear areas on chambers, and fine costae on the early part of the test.

The species is identical with $B$. spissa of Crouch and of Bandy and Arnal. It differs from B. spissa Cushman (1926, p. 45, pl. 6, fig. 8) in width, by lack of a distinct keel and strong costae on the early part of the test, and by having depressed sutures.

B. semiperforata differs from B. striatula Cushman (p. A19, this report) by its much larger size, broad sutures, chamber shape, and more rounded periphery.

\section{Bolivina (Bolivina) striatula Cushman}

Plate 30 , figures 9,10

Bolivina striatula Cushman, 1922, Carnegie Inst. Washington Pub. 311, p. 27, pl. 3, fig. 10.

Bolivina cf. B. karreriana H. B. Brady var. carinata Millett. Cushman and Wickenden, 1929, U.S. Natl. Mus. Proc., v. 75 , art. 9, p. 10 , pl. 4 , fig. 5 .

Bolivina advena Cushman var. striatella Cushman. Cushman and Moyer, 1930, Cushman Lab. Foram. Research Contr., v. 6, p. 58 , pl. 8 , fig. 6 .

Cushman and McCulloch, 1942, Allen Hancock Pacific Expedition, Repts., v. 6 , no. 4 , p. 187 , pl. 21, figs. 7-11.

Bolivina striatula Cushman var. spinata Cushman, 1936, Cushman Lab. Foram. Research, Spec. Pub. 6, p. 59, pl. 8, figs. $9 a, b$.

Test small, compressed, tapering; periphery subacute to narrowly keeled, smooth except for last chambers in largest specimens, which have posterior end of chamber produced into blunt spine; apparently not dimorphic; chambers very slightly inflated, early ones low, later ones much higher, lobed near median line; sutures slightly depressed, lobed, curving, oblique to periphery; early chambers with lower part of wall perforate, upper part clear, later chambers with wall peforate except for lobe near median suture; wall of early part of test with fine costae; aperture loop shaped with lip.

QUantitative Data (PL. i)

Observed depth range.-37 to 144 meters.

Abundance (I).-Extremely abundant in $\mathrm{C}-6$ and $\mathrm{C}-17$, rare in $\mathrm{C}-2(37 \mathrm{~m}), \mathrm{C}-20(47 \mathrm{~m}), \mathrm{C}-4(50 \mathrm{~m})$, $\mathrm{C}-18(6+\mathrm{m})$, and $\mathrm{C}-16(144 \mathrm{~m})$.

Length (II).-Distribution close to normal curve, but skewed to right, very similar for C-6 and C-17; standard range (S. R.) close to observed range
(O. R.) ; deviation from mean low; variability low.

Number of chambers (III).-No dimorphism apparent. Proloculus diameter varying, but with no sharp break. Smallest number of chambers observed, six pairs.

Width (IV).-Width increasing uniformly with length. Scatter tight.

Flare (V).-Variable in relation between growth index and length. Taper moderate.

Living specimens.-Abundant in $\mathrm{C}-6$ and $\mathrm{C}-17$; mean length slightly lower in both samples than that for dead specimens. Distribution in scatter diagrams conforming to that of dead specimens.

\section{DIAGNOSTIC FEATURES}

The test is small, with little variation in length. It is distinguished by its generally keeled periphery, curved sutures, clear areas, and fine costae. It is apparently not dimorphic.

The species inhabits shallow water; it was not found below 144 meters.

This form appears intermediate between $B$. striatula s. s. and $B$. striatula var. spinata Cushman. It is close to $B$. striatula s. s. in shape and in lack of apical spine but has costae and clear areas as does var. spinata. All three forms are assigned here to the same species.

Botivina cf. striatula Cushman of Höglund (1947, p. 266,267 , pl. 24 , fig. 4 , pl. 32 , figs. 14,15 ) appears identical with the described form, but no Höglund specimens were seen.

This species can be distinguished from $B$. semiperforata Martin (pp. A18, A19, this report) by its much smaller size, clear areas, more acute periphery, narrow depressed sutures, and costae. It closely resembles $B$. fragilis Phleger and Parker (1951, pt. 2, p. 13, pl. 6, figs. 14, 23, 24), which has a slightly wider keel and less curved sutures. $B$. fragilis should perhaps be included in the synonymy of B. striatula.

\section{Bolivina (Bolivina) minuta Natland}

Plate 30, figures 11,12

Bolivina minuta Natland, 1938, Scripps Inst. Oceanography Bull., Tech. Ser., v. 4, no. 5, p. 146, pl. 5, fig. 10.

?Bolivina minuta Natland. Cushman and McCulloch, 1942, Allen Hancock Pacific Expedition, Repts., v. 6, no. 4, p. 201, pl. 24, figs. 4-7.

?Loxostomum truncatum Phleger and Parker, 1951, Geol. Soc. America Mem. 46, pt. 2, p. 17, pl. 7, figs. 17, 18.

Bolivinita minuta (Natland). Bandy and Arnal, 1957, Am. Assoc. Petroleum Geologists Bull., v. 41, p. 2050.

Test small, compressed, tapering rapidly from subacute initial end; periphery flattened, concave, slightly lobed; thin and rectangular in transverse section; sutures distinct, raised, slightly curving, oblique to pe- 
riphery; chambers slightly depressed, first chamber less than $0.017 \mathrm{~mm}$ in diameter; wall thin, finely perforate; aperture loop shaped on apertural face of last chamber.

quantitative Data (PL. 8)

Observed depth range.-800 to 3,200 meters.

Abundance (I).-Abundant in C-9 and C-14, rare in $\mathrm{C}-11(3,200 \mathrm{~m})$ and $\mathrm{C}-13(1,600 \mathrm{~m})$.

Length (II).-Distribution extremely close to normal curve; standard range (S. R.) very close to observed range (O. R.) ; deviations small; variability $(V)$ low. Statistics very similar for C-14 and C-9.

Number of chambers (III).-No dimorphism apparent, proloculus diameter small. Scatter tight. Smallest number of chambers observed, five pairs.

Width (IV).--Increasing rapidly in width with increase in length.

Flare (V).-Length range of species too small and scatter too great to allow a meaningful axis to be drawn.

Living specimens.-Present in C-9 and C-14, distribution similar to that of dead ones.

DIAGNOSTIC FEATURES

The species is very small, with little variation in length. The test is very flat and tapers rapidly. Sutures are raised and limbate.

No dimorphism is apparent.

Mean length of specimens from C-9 and C-14 agrees closely with size of Natland's types. The form figured by Cushman and McCulloch (1942, pl. 24, figs. 4-7) apparently has more inflated chambers and more sinuous sutures and is apparently dimorphic; therefore it is only questionably assigned to $B$. minuta. Only a few specimens of Loxostomum truncatum were examined, but they appeared to belong to Natland's species.

\section{Bolivina (Bolivina) subadvena Cushman}

\section{Plate 30, figures 13-17}

Bolivina subadvena Cushman, 1926, Cushman Lab. Foram. Research Contr., v. 2, p. 44, pl, 6, figs. 6a, b.

Cushman, 1927, Scripps Inst. Oceanography Bull., Tech. Ser., v. 1, p. 156.

Natland, 1950, Geol. Soc. America Mem. 43, pt. 4, p. 22, pl. 5, figs. 20a, b.

Crouch, 1952, Am. Assoc. Petroleum Geologists Bull., v. 36, p. 830 , pl. 3, fig. 8 .

[not] Bolivina subadvena Cushman. Cushman, Stewart, and Stewart, 1930, San Diego Soc. Nat. History Trans., v. 6, p. 67, pl. 5, fig. 5 .

Cushman and Gray, 1946, Cushman Lab. Foram. Research, Spec. Pub. 19, p. 34, pl. 5, figs. 44a, b.

?Bolivina pomposa Coryell and Mossman, 1942, Jour. Paleontology, v. 16, p. 241 , pl. 36 , fig. 39.

Test robust, thick, variable, tapering evenly to subacute initial end in microspheric form, nearly parallel sided in megalospheric form; periphery broadly rounded to subacute; chambers numerous and increasing rapidly in size in microspheric form, few and increasing slowly in size in megalöspheric form; chambers only slightly inflated; proloculus diameter in microspheric form less than $0.017 \mathrm{~mm}$, in megalospheric form $0.07-0.020 \mathrm{~mm}$; sutures depressed, more or less strongly noded; wall coarsely perforate, in microspheric form with perforations on first few pairs of chambers forming single row; on some forms wall ornamented with fine costae on first $1 / 3$ to $1 / 2$ of test; aperture large, loop shaped, with well-developed lip.

QUANTITATIVE DATA (PL. 9)

Observed depth range. -435 to 1,700 meters.

Abundance (I) .-Abundant in C-15, C-8, C-14, C-9, rare in $\mathrm{C}-10, \mathrm{C}-13$.

Length (II).-Distribution different from normal curve, especially for microspheric form; standard range (S. R.) different from observed range (O. R.) ; deviations $(\mathrm{MD}, \sigma)$ high; variability $(V)$ large, about the same for all samples. Distribution of microspheric form very different from that of megalospheric; $V$ and length range much larger for microspheric form. Statistics very similar for samples from the same depth (C-15 similar to $\mathrm{C}-8, \mathrm{C}-9$ very similar to $\mathrm{C}-14, \mathrm{C}-13$ similar to $\mathrm{C}-10)$. Total abundance, range, and mean of length higher in C-14 and C-9 than in shallower or deeper samples.

Number of chambers (III).-Species very strongly dimorphic, shown by both proloculus diameter and number of chambers. Proloculus of megalospheric form large, globular, variable in diameter. Chambers very much higher in $\mathrm{C}-14$ and $\mathrm{C}-9$ than in $\mathrm{C}-15$ and $\mathrm{C}-8$. Smallest number of chambers observed: microspheric form, 6 pairs; megalospheric form, 1 pair.

Width (IV).-Width increasing faster throughout length range in C-14 and C-9 than in other samples. Scatter greater in C-14 and C-9. Dimorphism expressed in shape; megalospheric specimens much wider than microspheric at length less than $0.50 \mathrm{~mm}$.

Flare (V).-As shown by lower slope angles, species more flaring in $\mathrm{C}-14$ and $\mathrm{C}-9$ than in $\mathrm{C}-15$ and $\mathrm{C}-8$. Dimorphism shown; plotted separately for C-14 and C-9, axis for microspheric form with lower angle than that for megalospheric.

Living specimens.-Distribution similar to that of dead specimens.

DIAGNOSTIC FEATURES

The test is large and extremely variable. The periphery may be broadly rounded or subacute. Sutures may be strongly noded or curved. The perforations are extremely large. 
Bolivina subadvena is the most strongly dimorphic species present in these samples. The megalospheric proloculus is very large, and there is a great difference in number of chambers between the two forms.

Shape and size vary with depth, the optimum depth for the species being apparently at 800 to 900 meters.

Crenulation of the sutures of this species is extremely variable. The holotype has straight sutures, but topotypes show some crenulation. Specimens from Lydonia Station 30 (Cushman, 1927, p. 156) are identical with those from off the coast of El Salvador. $B$. pomposa Coryell and Mossman is only questionably included in the synonymy, as types are not available for examination.

Bolivina (Bolivina) tongi filacostata Cushman and McCulloch

Plate 30, figures 18,19

Bolivina tongi Cushman var. filacostata Cushman and McCulloch, 1942, Allen Hancock Pacific Expedition, Repts., v. 6, no. 4, p. 214-215, pl. 27, figs. 7-11.

Test small, compressed, early part rapidly tapering, later part nearly parallel sided, commonly widest near middle of test; periphery somewhat flattened, ornamented with several high thin costae; chambers slightly inflated; no dimorphism in proloculus size; sutures depressed, straight, oblique; wall perforate except for upper part of early chambers, which is clear; later part of test ornamented with continuous threadlike costae; aperture loop shaped, with thin lip.

QUANTITATIVE DATA (PL. 10)

Observed depth range. -80 to 1,700 meters.

Abundance (I).-Extremely abundant in C-6, common in $\mathrm{C}-17$, rare in $\mathrm{C}-16$ and $\mathrm{C}-8$, very rare in $\mathrm{C}-15$ $(435 \mathrm{~m})$ and $\mathrm{C}-10(1,700 \mathrm{~m})$.

Length (II).-Distribution normal, and in $\mathrm{C}-6$ and $\mathrm{C}-17$, where abundance is great, curve sharp; standard range (S.R.) and observed range (O.R.) very similar; deviation $(M D, \sigma)$ small; variability $(V)$ very low. Distribution very similar throughout depth range.

Number of chambers (III).-No dimorphism; scatter large. Proloculus diameter variable. Chambers of equal height in all samples. Smallest number of chambers observed, five pairs.

Width (IV).-Width increasing little beyond early part of test.

Flare (V).-Species nearly parallel sided beyond early part of test. More flaring in $\mathrm{C}-17$ than in other samples.

Living specimens.-None found.

DIAGNOSTIO FEATURES

The most characteristic feature of this species is the presence of fine costae running from the apertural end of the test towards the apical end. The costate part of the test was measured, and compared with the total length. No definite ratio between the two was found.

The geographic and geologic relations between this form and Bolivina tongi Cushman s. s. (Cushman Lab. Foram. Research Contr., v. 5, p. 93, pl. 13, figs. 29a, b, 1929) were not ascertained; however, the latter form is aparently restricted to the Tertiary. As $B$. filacostata is distinct from $B$. tong $i$ s. s., but is obviously related to it, it is retained as a subspecies.

\section{Bolivina (Bolivina) acuminata Natland}

Plate 30, figures 20, 21

Bolivina subadvena Cushman var. serrata Natland, 1938 [not Chapman, 1892], Scripps Inst. Oceanography Bull., Tech. Ser., v. 4 , no. 5, p. 145 , pl. 5, figs. 8,9 .

Cushman and McCulloch, 1942, Allen Hancock Pacific Expedition, Repts., v. 6, no. 4, p. 213 , pl. 26, fig. 14, pl. 27, figs. $1,2$.

Bolivina subadvena Cushman var. acuminata Natland. Cushman and Gray, 1946, Cushman Lab. Foram. Research, Spec. Pub. 19, p. 34, pl. 5, fig. 46.

Bolivina acuminata Natland, 1950, Geol. Soc. America Mem. 43, pt. 4, p. 22, pl. 5, figs. 21a, b.

Bandy and Arnal, 1957, Am. Assoc. Petroleum Geologists Bull., v. 41. p. 2050.

Test small, compressed, thickest at median line, tapering to acute serrate periphery; test tapering to subacute initial end in megalospheric form, to acute initial end in microspheric form; chambers only slightly inflated, keeled, posterior ends produced downward into spines; sutures depressed, curved; wall coarsely perforate; aperture small, loop shaped, with lip.

QUANTITATIVE DaTA (PL. 11)

Observed depth range. -47 to 450 meters.

Abundance (I).-Abundant in $\mathrm{C}-6, \mathrm{C}-17$, rare in $\mathrm{C}-16, \mathrm{C}-8$, and very rare in $\mathrm{C}-18(64 \mathrm{~m})$ and $\mathrm{C}-20$ $(47 \mathrm{~m})$.

Length (II).-Distribution not normal, too many small individuals; standard range (S. R.) and observed range (O. R.) dissimilar; variability $(V)$ moderate. Length range and mean fairly similar throughout depth range.

Number of chambers (III).-Dimorphism shown by proloculus diameter, but not by number of chambers. Scatter great. Chambers of equal height in all samples. Smallest number of chambers observed: microspheric form, 7 pairs; megalospheric form, 4 pairs.

Width (IV).-Scatter small, width increasing uniformly with length.

Flare (V).-Species moderately tapering, shown by angle of axis.

Living specimens.-Only one found, in C-17. 
DLAGNOSTIC FEATURES

The test is small and tapering. Its most distinctive feature is its serrate periphery. No strong dimorphism is shown.

No tendency toward a terminal aperture was noted, though Natland reported such an aperture on his specimens.

\section{Bolivina (Bolivina) vaughani Natland \\ Plate 30, figures 24, 25}

Bolivina vaughani Natland, 1938, Scripps Inst. Oceanography Bull., Tech. Ser., v. 4, no. 5, p. 146, pl. 5, fig. 11.

Bandy and Arnal, 1957, Am. Assoc. Petroleum Geologists Bull., v. 41, p. 2050.

Test very small, compressed, oval in cross section, tapering to subacute initial end; periphery rounded; chambers low, slightly inflated, with slight lobe on each side of median line; sutures depressed, distinct, bending around lobe, curved, oblique to periphery; wall finely perforate; aperture a small loop shaped opening on inner face of last chamber.

QUanTITATIVE DATA (PL. 12)

Observed depth range: 37 to 82 meters.

Abundance (I).-Abundant in $\mathrm{C}-6, \mathrm{C}-17$, rare in $\mathrm{C}-2(37 \mathrm{~m}), \mathrm{C}-20(47 \mathrm{~m})$, and $\mathrm{C}-4(40 \mathrm{~m})$.

Length (II).-Distribution normal; standard and observed ranges (S.R., O.R.) similar, very small; deviations small : variability $(V)$ very low.

Number of chambers (III).-No dimorphism; wide scatter; number of chambers increasing rapidly. Smallest number of chambers observed, seven pairs.

Width (IV).-Width increasing little with length.

Flare (V).-Length range too small, scatter too great to allow meaningful axis to be drawn.

Living specimens.-None found.

DIAGNOSTIC FEATURES

The species is extremely small, and parallel sided. The most distinctive feature is the presence of lobes on the median part of the chambers. No dimorphism was found.

The species occurs only in shallow depths.

Bolivina (Bolivina) inflata Heron-Allen and Earland

Plate 30, figures 22, 23

Bolivina inflata Heron-Allen and Earland, 1913, Roval Irish Acad. Proc., r. 31 , pt. 64 , p. 68 , pl. 4 , figs. 16-19.

Cushman, 1937, Cushman Lab. Foram. Research, Spec. Pub. 9, p. 166, pl. 18, fig. 16 .

Test small, rapidly tapering from subacute initial end; periphery broadly rounded; chambers much inflated, increasing rapidly in size, so that terminal end appears inflated; sutures distinct, depressed, fairly straight, oblique; wall finely perforate, white; aperture loop shaped, with no lip.
QUANTITATIVE DATA (PL. 13)

Observed depth range. -47 to 450 meters.

Abundance (I).-Common in $\mathrm{C}-6, \mathrm{C}-17$, rare in $\mathrm{C}-8$, very rare in $\mathrm{C}-20(47 \mathrm{~m})$, and $\mathrm{C}-16(144 \mathrm{~m})$.

Length (II).-Distribution near normal, range small; variability $(V)$ low. Size about the same throughout depth range.

Number of chambers (III).-No dimorphism. Scatter great. Smallest number of chambers observed, six pairs.

Width (IV).-Width increasing rapidly and uniformly with length.

Flare (V).-Length range too small, scatter too great to allow calculation of meaningful axis, except in $\mathrm{C}-17$, where taper is moderately low.

Living specimens.-None found.

DIAGNOSTIC FEATURES

This species is small and rare. It is distinguished by the globular shape of its chambers, its evenly tapering form, and silvery appearance. It is not dimorphic.

Bolivina globulosa Cushman (Cushman Lab. Foram. Research Contr., v. 9, p. 80 , pl. 8 , fig. 9,1933 ) is very similar to this species, and should perhaps be included in the synonymy of $B$. inflata.

\section{Bolivina (Bolivina) pseudobeyrichi Cushmän}

Plate 31, figures $3-8$

Bolivina beyrichi Ruess var. alata Cushman, 1911 [not Seguenza], U.S. Natl. Mus. Bull 71, pt. 2, p. 35, fig. 57.

Bolivina pseudobeyrichi Cushman, 1926, Cushman Lab. Foram. Research Contr., v. 2, p. 45.

Cushman, 1927, Scripps Inst. Oceanography Bull., Tech. Ser., v. 1, no. 10 , p. 156 , pl. 3, fig. 7 .

Cushman, 1937, Cushman Lab. Foram. Research, Spec. Pub. 9 , p. $139-140$, pl. 19, figs. 4 , 5 .

Test large, fragile, tapering rapidly from subacute initial end, occasionally tending to become uniserial; periphery except for first few chambers usually with broad keel, produced downwards at ends of chambers into long fragile spines; some with narrower keel, shorter spines; chambers inflated, increasing rapidly in size as added; sutures depressed, curved, oblique to periphery; proloculus round, inflated, first pair of chambers wrapping half way around it, proloculus diameter of microspheric form less than $0.017 \mathrm{~mm}$, of megalospheric form $0.025-0.075 \mathrm{~mm}$; wall finely perforate, transparent, showing internal structure; aperture large with flaring lip, well-developed internal tooth.

QUANTITATIVE DATA (PL. 14)

Observed depth range. -435 to 1,700 meters.

Abundance (I).-Common in $\mathrm{C}-8, \mathrm{C}-14, \mathrm{C}-9$, rare in $\mathrm{C}-13$, very rare in $\mathrm{C}-15(435 \mathrm{~m}), \mathrm{C}-10(1,700 \mathrm{~m})$. 
Length (III).-Distribution not near normal curve; length range large; variability $(V)$ high. Distribution and statistics similar throughout depth range.

Number of chambers (III).-Weakly dimorphic, shown by proloculus diameter and by number of chambers. Few microspheric specimens present. Chambers higher in C-14 and C-9 than in C-8. Smallest number of chambers observed: microspheric form, 4 pairs; megalospheric form, 2 pairs.

Width (IV).-Width increasing very rapidly with increase in length. Scatter moderate. Dimorphism not shown.

Flare (V).--Rapid taper shown by low angle of axis. Most flaring in C-14 and C-9.

Living specimens.-Distribution of living specimens conforms to that of dead.

DIAGNOSTIO FEATURES

The test is large, fragile, and transparent. The chambers are inflated, and the early chambers are wrapped around the proloculus. The typical form has a wide fragile keel, but this appears not to be present on specimens from relatively shallow water.

The aperture is large, with a well-defined tooth, and tends to become terminal in largest specimens.

These specimens agree closely with forms figured by Cushman (1911, 1937). Great variation in width of keel is shown: forms in C-8 $(450 \mathrm{~m})$ and $\mathrm{C}-15$ (435 m) ) (pl. 31, figs. 6,7) lack the broad fragile keel found on specimens in deeper samples (pl. 31, figs. 3-5). Except for this difference, specimens from all samples are identical. Possibly the narrow-keeled form should be considered a subspecies.

As the keel and spines are very fragile, the widths measured for all specimens exclude the keel.

\section{Bolivina (Bolivina) bradyi Asano}

Plate 31, figures 1, 2

Bolivina beyrichi Reuss. Cushman, 1911, U.S. Natl. Mus. Bull. 71 , pt. 2 , p. 34-35, fig. 56 .

Bolivina bradyi Asano, 1938, Geol. Soc. Japan Jour., v. 45, no. 538 , p. 603 , pl. 16 , fig. 2.

?Loxostoma instabile Cushman and McCulloch, 1942, Allen Hancock Pacific Expedition, Repts., v. 6, no. 4, p. 221-222, pl. 28, figs. 6, 7 [not pl. 27, figs. 15-17, pl. 28, figs. 1-5].

Test compressed, tapering, tending to become uniserial; periphery subacute to subrounded; chambers slightly inflated, increasing rapidly in size as added, posterior ends of chambers produced downwards into sharp spines; proloculus varying in size, but without showing sharp dimorphism; sutures depressed, curved, oblique; wall coarsely perforate except for upper inside corners of chambers, which are clear, imperforate; aperture large, with lip and well-developed internal tooth.

QUANTITATIVE DATA (PL. 15)

Observed depth range.-80 to 450 meters.

Abundance (I).--Rare in $\mathrm{C}-6$ and $\mathrm{C}-17$, very rare in $\mathrm{C}-8(450 \mathrm{~m})$.

Length (II).-Distribution flat, but standard range (S. R.) similar to observed range (O. R.) ; deviations $(\mathrm{MD}, \sigma)$ moderate; variability $(V)$ moderate.

Number of chambers (III).-Scatter great. No dimorphism, proloculus diameter variable. Smallest number of chambers observed, six pairs.

Width (IV).--Increasing evenly but slowly with increasing length.

Flare (V).--Rate of taper moderate, scatter great.

Living specimens.--None found.

DIAGNOSTIC FEATURES

The species is quite similar to $B$. pseudobeyrichi but is distinguished from that species by being much narrower. The narrow keel is produced into spines. It is probably an ecologic variant of $B$. pseudobeyrichi (see pp. A22, A23 and fig. 13), but too few specimens were found to confirm the relationship.

No dimorphism was found.

Subgenus LOXOSTOMUM Ehrenberg, 1854

Type species.-Loxostomum subrostratum Ehrenberg. Early part of test like Bolivina s. s., later tending to become uniserial; aperture of early part like that of Bolivina, later tending to become terminal and oval.

Bolivina (Loxostomum) boltovskoyi, n. sp.

Plate 31, figures 9, 10

Bolivina bramlettei Kleinpell. Cushman and McCulloch, 1942, Allen Hancock Pacific Expedition Repts., v. 6, no. 4, p. 189-190, pl. 22, fig. 7 [not figs. 8-13].

Test large, robust, thick, tending to become uniserial; periphery broadly rounded, lobed; test tapering to subacute initial end; chambers inflated, increasing rapidly in size, later chambers with posterior ends tending to be produced into spines; sutures depressed, slightly curved, oblique; wall finely perforate, thin; aperture large, tending to become terminal, with well-developed internal tooth.

QUANTITATIVE DATA (PL. 16)

Observed depth range. -435 to 450 meters.

Abundance (I).-Common in C-8 and C-15.

Length (II).-Distribution near normal curve; standard range (S. R.) smaller than observed range (O. R.) ; variability (V) moderate. 
Number of chambers (III).-No dimorphism in number of chambers, although weakly dimorphic in proloculus diameter. Smallest number of chambers observed, three pairs.

Width (IV).--Increasing rapidly in early part of test, more slowly in later part. Dimorphism not shown.

Flare (V).-Rate of taper great, shown by low angle of axis. More flaring in C-8 than C-15.

Living specimens.-Distribution like that of dead specimens.

DIAGNOSTIC FEATURES

The test is large, with broadly rounded periphery. The ends of the later chambers overlap previous chambers and form spines. Chambers are inflated, and the wall is translucent. The aperture is very large and terminal.

The depth range is restricted.

This form differs from Loxostomum instabile Cushman and McCulloch (1942, p. 221-222, pl. 27, figs. 16-17, pl. 28, figs. 1-7) by its larger size, rounder periphery, and more inflated chambers. It does not tend to become so distinctly uniserial as that species.

Holotype: USNM 626567, from sample C-15, lat. $12^{\circ} 12.0^{\prime}$ N., long. $88^{\circ} 08.2^{\prime}$ W., from $435 \pm$ meters.

Bolivina (Loxostomum) salvadorensis, n. sp.

Plate 31, figures 11, 12

Test elongate, flat, narrow, tending to become uniserial; periphery smooth, rounded; test tapers evenly to subácute initial end; chambers numerous, not inflated, later chambers high; sutures only slightly depressed, broad, white; wall finely perforate, except for upper parts of later chambers, which are clear, imperforate; aperture large, tending to become terminal, but with lip extending to base of chamber, and with well-developed internal tooth.

QUANTITATIVE DATA (PL. 17)

Observed depth range. -435 to 885 meters.

Abundance (I).-Rare in $\mathrm{C}-15, \mathrm{C}-8$, very rare in $\mathrm{C}-9(885 \mathrm{~m})$.

Length (II).-Distribution flat, skewed to right (many large individuals); deviations moderate; standard range (S. R.) near observed range (O. R.) ; variability (V) low. Statistics for $\mathrm{C}-8$ and $\mathrm{C}-15$ very similar.

Number of chambers (III).--Dimorphism questionable; only one microspheric(?) form found; megalospheric(?) proloculus diameter variable.

Width (IV).--Relation of length and width variable, maximum width of many long forms less than that of shorter forms. In general, width increases very gradually with increase in length.

Flare (V).-Scatter great, axis slope steep, indicating nearly parallel-sided species.

Living specimens.-Abundant in C-15; distribution corresponding to that of dead specimens.

DIAGNOSTIC FEATURES

The test is large and flat, with rounded periphery. The sutures are limbate, white, and flush with the surface. The chambers are not inflated, and the periphery is smooth.

The flatness and lack of chamber inflation distinguish this species from B. mayori Cushman (1922, p. 27, pl. 3, figs. 5,6 ).

Holotype: USNM 626569 , from sample C-15, lat. $12^{\circ} 12.0^{\prime}$ N., long. $88^{\circ} 08.2^{\prime} \mathrm{W}$., from $435 \pm$ meters.

\section{Genus SUGGRUNDA Hoffmeister and Berry, 1937}

Test biserial, minute, elongate, tapering, tending to be twisted; chambers somewhat angular, tending to be spinose; walls calcareous, hyaline, rather coarsely perforate; aperture semilunate at base of apertural face.

This genus is closely related to Bolivina, differing mainly in shape and position of the aperture.

\section{Suggrunda eckisi Natland}

Plate 31, figures 13, 14

Bolivina pygmaea H. B. Brady. Cushman and Moyer, 1930, Cushman Lab. Foram. Research Contr., v. 6, pt. 3, p. 57, pl. 8 , fig. 4 .

Suggrunda eckisi Natland, 1950, Geol. Soc. America Mem. 43, pt. 4, p. 23, pl. 9, fig. 12.

Test small, tapering from subacute initial end, oval in cross section; periphery broadly rounded, posterior parts of later larger chambers produced into downwardprojecting spines; chambers numerous, slightly inflated; sutures depressed, nearly straight, slightly oblique to periphery; proloculus diameter $0.01 \mathrm{~mm}$; wall finely perforate, uppermost part of chambers on most specimens clear; aperture a slit at base of apertural face.

QUANTITATIVE Data (PL. 18)

Observed depth range. -64 to 3,200 meters.

Abundance (I).-Abundant in $\mathrm{C}-6, \mathrm{C}-17$, common in $\mathrm{C}-9, \mathrm{C}-8, \mathrm{C}-14$, rare in $\mathrm{C}-16, \mathrm{C}-10$, and very rare in $\mathrm{C}-18(64 \mathrm{~m}), \mathrm{C}-15(435 \mathrm{~m}), \mathrm{C}-13(1,600 \mathrm{~m})$, and $\mathrm{C}-11$ $3,200 \mathrm{~m})$.

Length (II).-Distribution like normal curve; standard range (S. R.) and observed range (O. R.) similar; deviations small; variability $(V)$ low. Mean length and range decrease slightly with increasing depth. 
Number of chambers (III).-No dimorphism; scatter great. Chambers equal in height in all samples.

Width (IV).-Width increasing rapidly with length, scatter great.

Flare (V).-Scatter great, length range too small to allow meaningful axis to be drawn.

Living specimens.-Only one found, in C-17.

DIAGNOSTIC FEATURES

The species is small, with low chambers whose posterior ends are produced into spines. No dimorphism was observed.

The depth range is very great.

Suggrunda eckisi is very similar to S. kleinpelli Bramlette (Woodring and Bramlette, 1950, p. 59, pl. 23, figs. 4, 5, and 9), differing by having straighter less oblique sutures.

\section{FAUNAI DISTRIBUTION}

Plates 19 to 27 represent the nine samples for which statistical data were compiled, showing the species present in each sample and the variations between these species in size, shape and abundance. Figure 8 shows the relative abundance of each species in each sample and the depth range of each species within the 80- to 1,700-meter depth range.

Three samples (C-6, C-17, and C-16) are from the continental shelf, and are within the photic zone. C-6 and $\mathrm{C}-17$ are from nearly the same depth (80,82 meters) and their faunas are very similar. C-16 is from 144 meters, and is quite dissimilar from shallower or deeper samples. The main characteristic of the shallow faunas is the predominance of small species (Botivina striatula, $B$. acuminata, $B$. vaughani, and $B$. inflata). Some large species are present, but form a relatively small percentage of the total fauna.

The 6 samples from 400 to 1,700 meters $(\mathrm{C}-15, \mathrm{C}-8$; C-14, C-9; C-13, C-10 [pls. 22-27]), from the continental slope, all contain similar faunas. All have a prevalence of large species, Bolivina seminuda, $B$. semiperforata, $B$. argentea, $B$. subadvena, and $B$. pseudobeyrichi, whereas small species compose a relatively small proportion of the faunas. The 6 samples in this depth range are 3 depth pairs; of these 3 pairs, C-14 and C-9 $(800+\mathrm{m})$ contain the largest and most flaring specimens. Each member of a pair is more similar to the other member than to any other sample.

In summary, the following general trends in the Bolivina faunas can be found: Faunas from the continental shelf vary rapidly in composition with increasing depth, whereas composition of slope faunas changes little. The shelf species are generally small, with mean lengths around $0.25 \mathrm{~mm}$; the slope faunas are composed of larger forms, with mean lengths about $0.50 \mathrm{~mm}$. Loxostomum species are present only on the upper part of the slope. Suggrunda eckisi is present at all depths from which collections were made.

\section{CONCLUSIONS}

The quantitative and qualitative analyses of the bolivinid faunas have contributed information on four problems: (a) Uniformity of faunas from similar ecologic niches; (b) accumulation in place versus downslope movements: (c) statistical differentiation of species; and (d) variation within species under different ecologic conditions. The ecologic factors that control the distribution of bolivinids can be surmised from these data.

Quantitative and qualitative data for all species are summarized in plate 28. All line drawings of all species are at the same scale; where present, both microspheric and megalospheric forms are shown. Qualitative descriptions of morphologic characters include periphery, character of sutures, and 'ornamentation.

Quantitative data include depth ranges and changes with depth. Changes with depth include length parameters, growth index parameters, number of chambers, and proloculus diameter. The quantities are shown for each sample, and are plotted against depth.

Length and growth index data are shown as bar diagrams, described fully by Hubbs and Perlmutter (1942), and Hubbs and Hubbs (1953). The diagrams show observed range (O. R.), standard deviation $(\sigma)$, mean $(\mathrm{M})$, and the standard error of the mean $\left(\sigma_{M}\right)$. These parameters are very useful in determining differences or similarities within species between different samples. The standard deviation indicates dispersion about the mean, and is independent of the frequency of measured specimens. The standard error of the mean (see p. A14) is dependent on the frequency of measured specimens, and hence is a measure of reliability of the mean. A distance of $2 \sigma_{\mathrm{M}}$ on either side of the mean should include 96 percent of possible values of the mean. Therefore, if there is no overlap of this value for two samples, the difference can be considered significant. Hubbs and Hubbs (1953, p. 55, fig. 4) provide a graph by which probable significance of observed differences between any two samples can be obtained. For the purposes of this report it is sufficient to assume that differences are significant if the $2 \sigma_{\mathrm{M}}$ bars for different samples do not overlap.

Values for number of pairs of chambers and proloculus diameter are given separately for microspheric and megalospheric forms. 


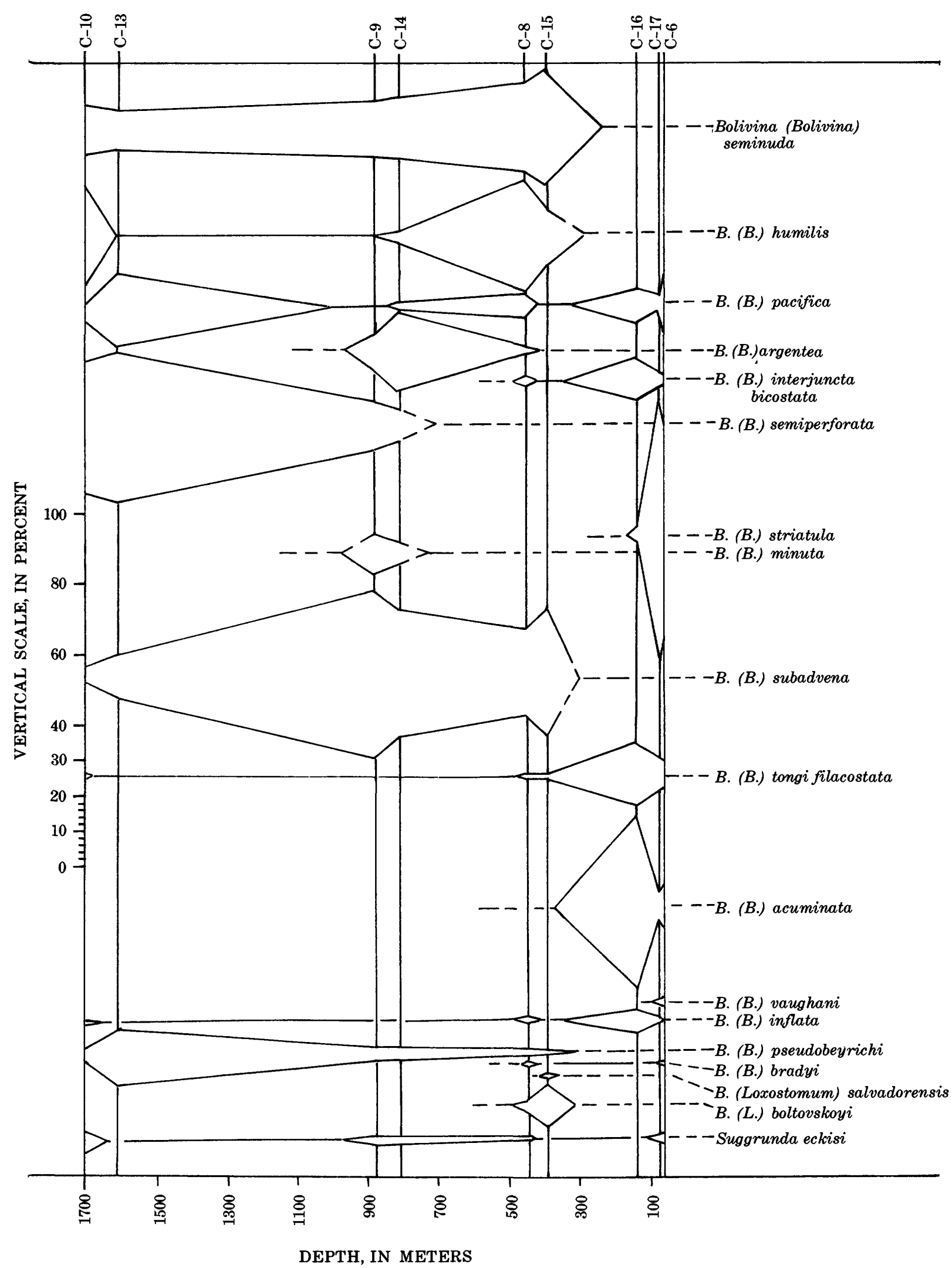

Figure 8.-Distribution and range of bolivinid species. 


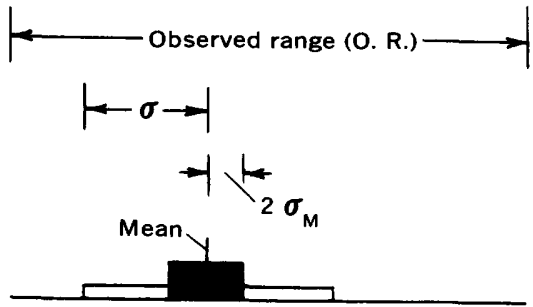

Figure 9.-Bar diagram for comparison of parameters of range and mean. (See pl. 28. Range (O.R.) is shown by the basal black line; the mean (M), by a vertical line. The blackened bar equals two standard errors of the mean $\left(\sigma_{M}\right)$ on either side of $M$. The white bar equals one standard deviation $(\sigma)$ on either side of $M ; \sigma$ indicates dispersion ; $2 \sigma_{M}$. reliability.

\section{FAUNAL UNIFORMITY}

The samples described in this report were taken in pairs from nearly identical depths (figs. 1,2 ; table 1 ). This was done to test the uniformity of faunas from the same habitat. As shown in figure 8, the results are encouraging, as data from paired samples are in fact very similar. Not only are species present in depth pairs the same, but statistical data are also similar. For example, an examination of data for two variable species, Bolivina seminuda (pl. 1) and B. subadvena (pl. 9), reveals that data for the depth pairs $\mathrm{C}-15$ and $\mathrm{C}-8$ are similar, as are data for $\mathrm{C}-9$ and $\mathrm{C}-14$. However, $\mathrm{C}-8$ and $\mathrm{C}-15$ are different from $\mathrm{C}-9$ and $\mathrm{C}-14$. The same comparison can be made between other samples for other species. It appears from these examples that a single sample is probably representative of samples taken from that depth anywhere in the area.

\section{ACCUMULATION OF SAMPLES}

A serious problem in evaluating a faunal sample is the question of indigenous accumulation versus transportation to the locality by downslope movements. One method of resolving the problem is comparison of living and dead specimens from the same sample; probably the living specimens are in place. In most of these samples, living specimens of bolivinids are present, abundantly in some. The size and shape distribution of these living forms conforms to that of dead forms in all cases, indicating that probably the dead forms are in place also. Another check on the problem is provided by analysis of plate 28 and of the species charts for variable species. For example, the length, height of chambers, and flare of Bolivina subadvena (pl. 9, columns II and V) are significantly greater in sample C-14 $(800 \mathrm{~m})$ than in $\mathrm{C}-8(450 \mathrm{~m})$, and points cluster tightly along the axes in both samples. A similar change occurs in Bolivina seminuda (pl. 1) in the same samples. These examples indicate that there has been no mixing of the two faunas.

It is very probable, therefore, that the dead population in this area is related to the living population and that statistics for the dead faunas can be regarded as representing faunas in situ.

\section{STATISTICAL DIFFERENTIATION OF SPECIES}

In this paper, 18 different species belonging to the subfamily Bolivinidae have been distinguished. Plate 28 is a key to the species of Bolivina and Suggrunda herein discussed, presenting both quantitative and qualitative characteristics. No single character, either quantitative or qualitative, can be used to distinguish all species.

For the initial classification into species, only qualitative criteria of morphology-shape, sutures, ornamentation, and other characteristics-were used. On the basis of these characters, 8 of the 18 species are distinct: Bolivina minuta, $B$. subadvena, $B$. tongi filacostata, B. acuminata, B. vaughani, B. inflata, B. salvadorensis, and Suggrumda eckisi. The other 10 fall into 4 groups: (a) Bolivina seminuda group (B. seminuda, $B$. humilis, B. pacifica) ; (b) Bolivina argentea group ( $B$. argentea, $B$. interjuncta bicostata) ; (c) Bolivina striatula group ( $B$. striatula, B. semiperforata); and (d) Bolivina pseudobeyrichi group (B. pseudobeyrichi, $B$. bradyi, Loxostomum boltovskoyi). The members of each of the four groups are similar to each other in form, and so possible intergradation between the supposed species was tested by quantitative methods. Triangular graphs (Burma, 1948, p. 755, 756) were composed on which three quantitative parameters (length, number of pairs of chambers, and length to width ratio) are compared. Actual values are not plotted, but rather their percentage contribution to the sum of the characters. To give as wide a spread on the graph as possible, the parameters were given approximately equal weights: $x$ (length) $+x$ (number of pairs of chambers $\times 4$ ) $+x$ (length to width $\times 10)=100$ percent. The percentages are plotted on the graphs, which show only the proportions between the (weighted) parameters.

Bolivina seminuda group.-Bolivina seminuda, $B$. humilis, and $B$. pacifica are morphologically similar; all have broadly rounded peripheries and all have the upper part of chambers clear and imperforate. The three species have different but overlapping depth ranges. Quantitatively, Bolivina seminuda is a large strongly dimorphic form with a moderate flare. $B$. humilis is a small form with flare only slightly less than that of $B$. seminuda, with slightly noded sutures, and only weak dimorphism. $B$. pacifica is close in size to $B$. humilis, but can easily be distinguished from the latter by its smaller flare, lack of dimorphism in most samples, 
and oblique sutures. A triangular diagram for these three species (fig. 10), from C-15, bears out the above observations.

The fields of the microspheric and megalospheric forms of $B$. seminuda are widely separated; the microspheric forms occurs within the field of $B$. humitis, but the megalospheric forms show almost no overlap. $B$. humitis shows weak dimorphism. $B$. pacifica shows almost no overlap with either of the other species.

Bolivina argentea group.-Bolivina argentea and $B$. interjuncta bicostata resemble each other, but can be easily distinguished. Bolivina argentea has a distinct keel, limbate sutures, and a silvery opalescent wall; $B$. interjuncta bicostata lacks these features. Quantitative data show that $B$. argentea is larger, more rapidly tapering, and more strongly dimorphic. A triangular graph of the two species (fig. 11) shows these differences graphically. B. interjuncta biscostata shows weak dimorphism, and occupies a very compact field. $B$. argentea shows strong dimorphism, and its field only slightly overlaps that of the other species. The two species are unfortunately from different samples, but the separation appears great enough to indicate that the two are different species.

Bolivina striatula group.-B. striatula and B. semiperforata are quite similar in appearance, both having clear areas on the chambers and strongly oblique sutures. $B$. semiperforata can be distinguished by its much larger size and strong dimorphism (B. striatula is not dimorphic), as well as by the shape of the chambers and character of the sutures. The depth ranges are very different, $B$. striatula ranging no deeper than 144 meters and $B$. semiperforata no shallower than 800 meters. A triangular graph for the two species (fig. 12) shows the strong dimorphism of $B$. semiperforata by the wide gap shown between the distribution fields for the microspheric and megalospheric forms. The field of the microspheric form and the small compact field of $B$. striatula overlap slightly.

Bolivina pseudobeyrichi group.-This group includes representatives of two subgenera of the genus Bolivina-Bolivina s. s. (B. pseudobeyrichi, and B. bradyi), and Loxostomum (B. boltovskoyi). All have inflated, similarly shaped chambers, thin transparent walls, and similar apertures. B. pseudobeyrichi is the largest and most rapidly tapering of the three forms, and usually has a wide fragile keel. $B$. bradyi is very similar, differing in being more elongate and narrow. $B$. boltovskoyi is obviously related to the other two, but has a broadly rounded periphery. The depth ranges of the three species overlap. A triangular graph of Botivina pseudobeyrichi (sample C-8) and B. bradyi $(\mathrm{C}-6)$ is given in figure 13. Very little difference is shown between the two species. However, since $B$. bradyi is very rare, no definite conclusion can be drawn: It is possible that $B . b r a d y i$ is an ecologic variant of $B$. pseudobeyrichi. $B$. boltovskoyi is not shown as it is distinguished from the other two species by its broadly rounded periphery.

Consideration of available data appears to show the validity of most of the above species; however, even if each group were reduced to a single species, 12 species of bolivinids would still be distinguishable. Moreover, there would still be 9 species from the 6 square inches of core surface of samples C-8 and C-6 and 7 species from C-9 (6 living). The fact that so many of these species occur together in the same samples possibly indicated a response to microenvironments within each sample. For example, some species may live in the bottom mud, others at the water-mud interface.

\section{VARIATION WITHIN SPECIES WITH DEPTH}

One of the most important conclusions to be drawn from the data herein compiled is the amount and type of variation within species as a function of depthand (or) ecology. On plate 28 variations are plotted against depth for each species.

Some species show little variation with depth. In general, these are the species with low coefficient of variability $(V)$ and tight scatter on all diagrams. These species are Bolivina pacifica, $B$. semiperforata, B. minuta, B. tongi filacostata, and Suggrunda eckisi. For some species the depth range is too small to determine whether variation is present or not.

Bolivina humilis is remarkably uniform throughout its depth range, except that for intermediate depth samples its proloculi show dimorphism, while for shallow and deep samples all proloculi have the same diameter.

Species which show great variation with change in depth also are highly variable in morphology and show a correspondingly broad scatter on variation diagrams. These variable species are Bolivina seminuda, $B$. interjuncta bicostata, B. subadvena, and B. pseudobeyrichi. Variations of these species are described below.

Bolivina seminuda.- This species varies both quantitatively and qualitatively with depth. It is constant in shape, but varies in the number of chambers having clear areas. In the shallower samples $(\mathrm{C}-15, \mathrm{C}-8)$ most specimens have clear areas on all chambers; in the deeper samples, most specimens have clear areas only on the last chambers. In samples $\mathrm{C}-9$ and $\mathrm{C}-14$, the species reaches a maximum in size, height of chambers, flare, and megalospheric proloculus diameter. Maximum abundance occurs in C-14. Differences of length means and growth index means between $\mathrm{C}-9$ and $\mathrm{C}-14$, and $\mathrm{C}-8$ and $\mathrm{C}-15$ are significant. 


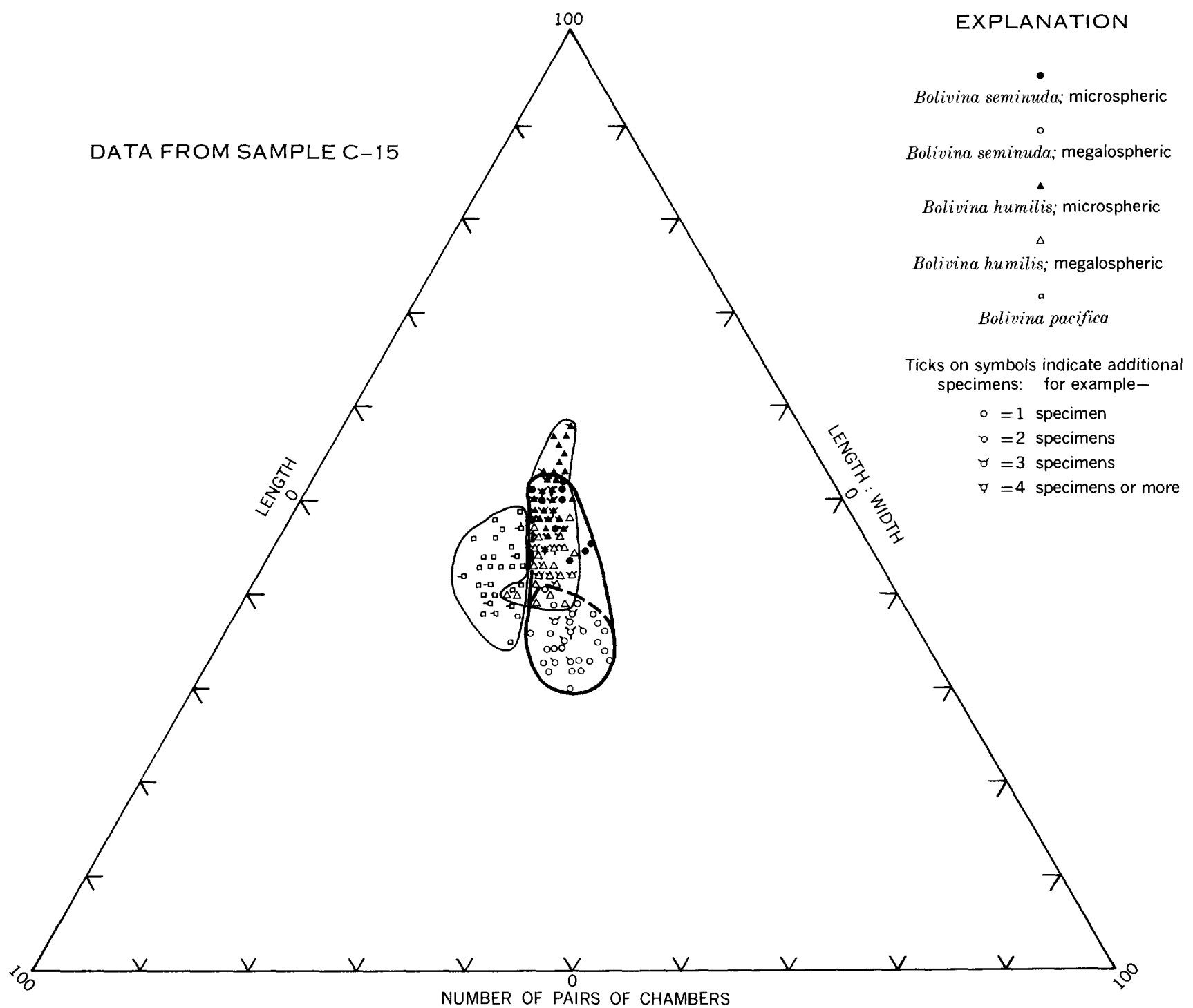

FIGURE 10.-Triangular diagram showing percentage contribution of length, number of pairs of chambers, and length to width ratio $[X$ (length) $+X$ (number of pairs of chambers $\times 4)+X$ (length to width $\times 10)=100$ percent $]$. 


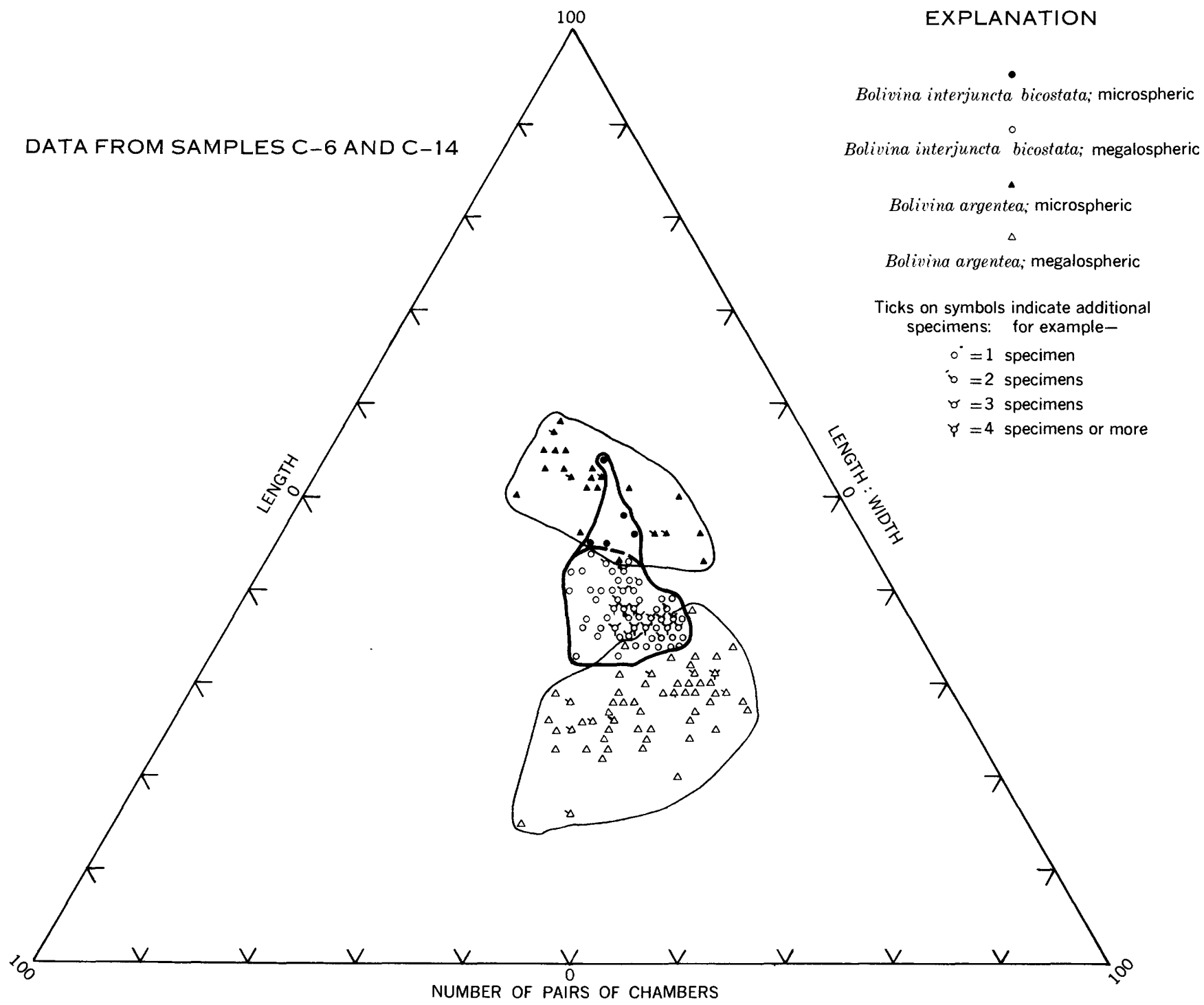

FraUre 11-Triangular diagram showing percentage contribution of length, number of pairs of chambers, and length to width ratio $[X$ (length) $+X$ (number of pairs of chambers $\times 4)+X($ length to width $\times 10)=100$ percent $]$. 


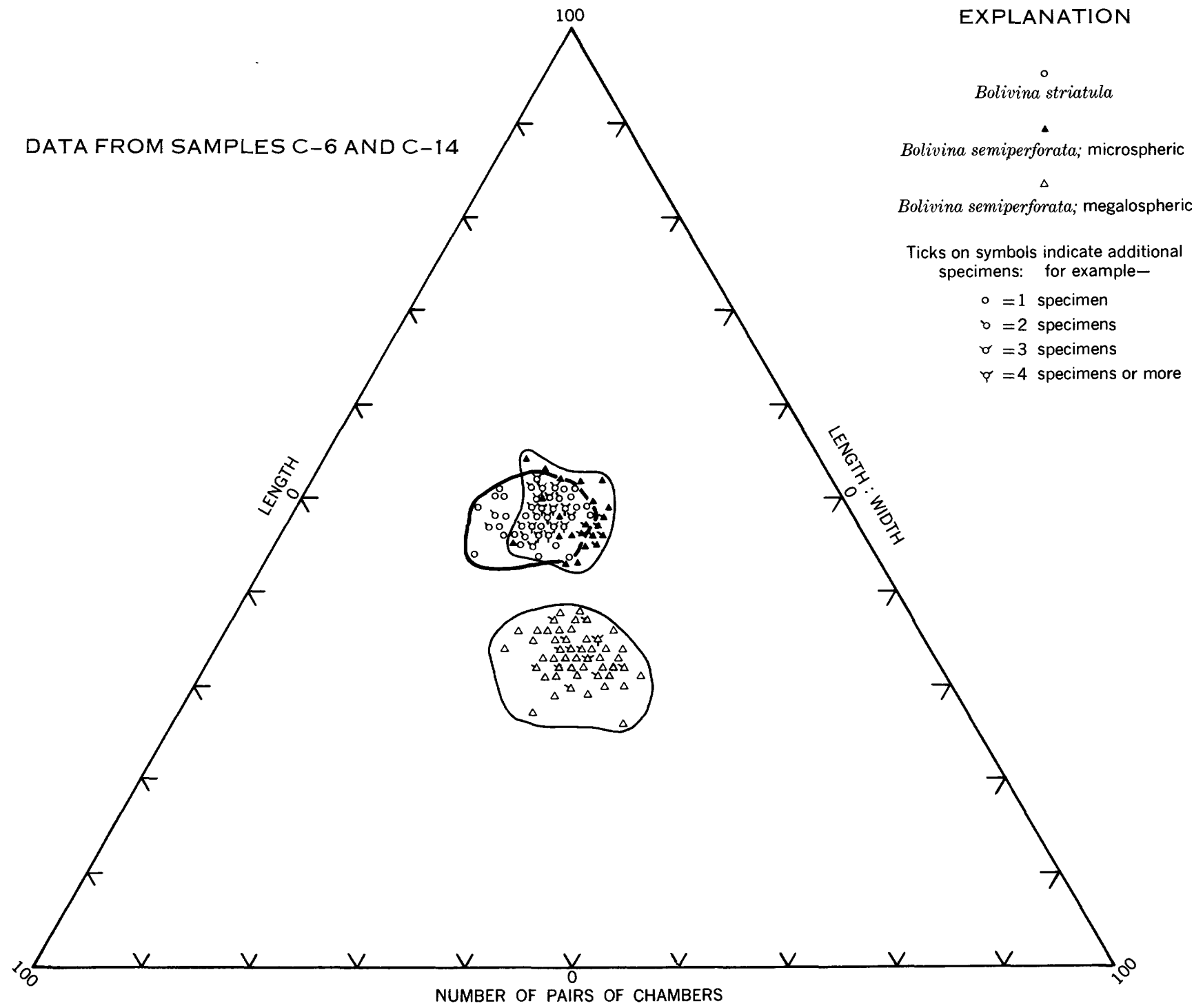

FigURE 12.-Triangular diagram showing percentage contribution of length, number of pairs of chambers, and length to width ratio $[X$ (length) $+X$ (number of pairs of chambers $\times 4)+X$ (length to width $\times 10)=100$ percent $]$. 


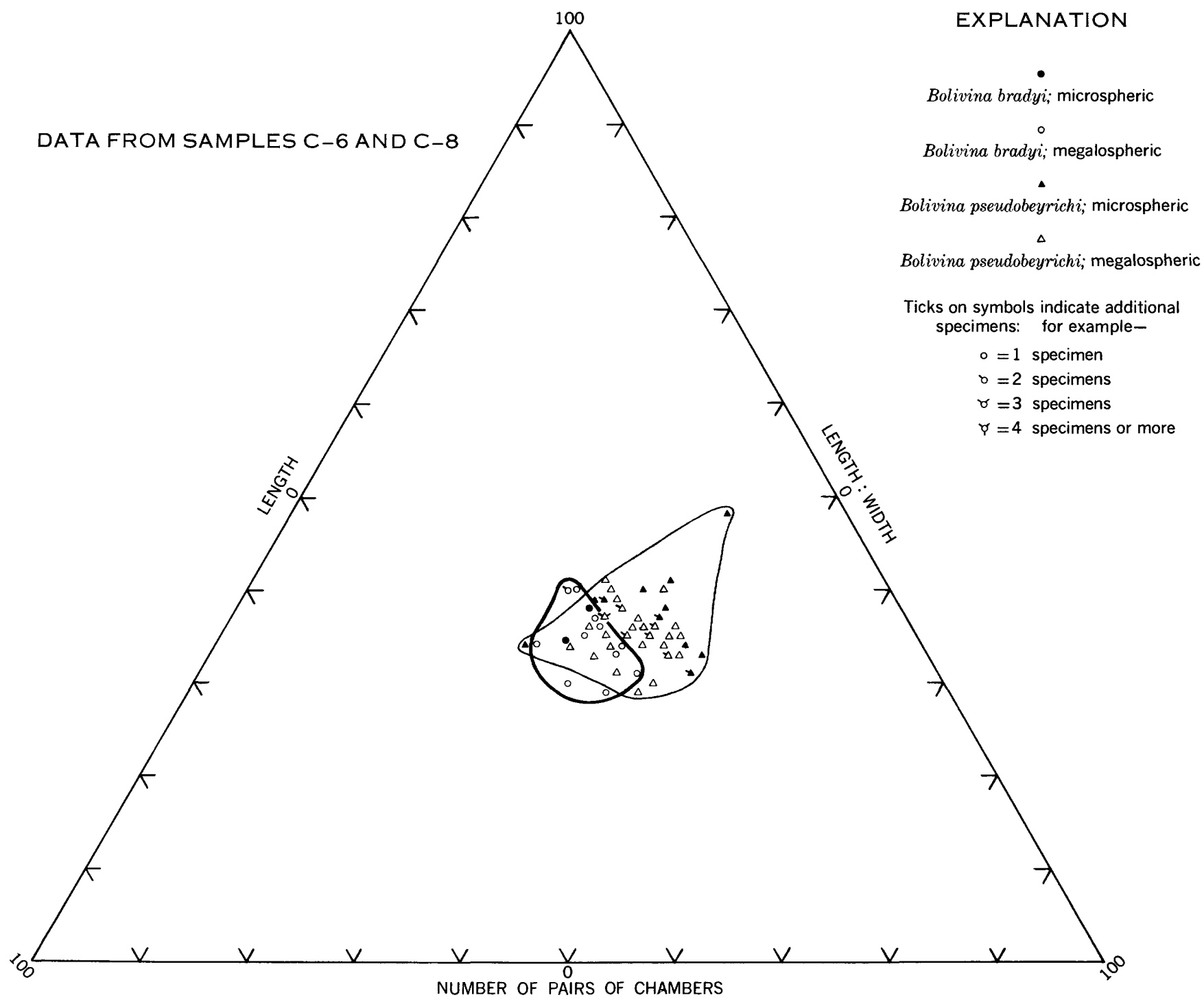

FIGURE 13.-Triangular diagram showing percentage contribution of length, number of pairs of chambers, and length to width ratio $[X$ (length) $+X($ number of pairs of chambers $\times 4)+X$ (length to width $\times 10)=100$ percent $]$. 
Bolivina interjuncta bicostata.-This species has a small depth range, but shows some variation in size, number of chambers, and megalospheric proloculus diameter with changing depth.

Bolivina subadvena.-This form is extremely variable in width, periphery, and amount of suture crenu. lation; these variations occur in all samples. There is also a distinct change with depth; a wide gap is shown between the mean lengths for $\mathrm{C}-9$ and $\mathrm{C}-14$ and those for $\mathrm{C}-8$ and $\mathrm{C}-15$, indicating a significant difference in means. Specimens in C-9 and C-14 are more abundant, much larger, have higher chambers, larger megalospheric proloculi, and are more flaring than those of deeper or shallower samples.

Bolivina pseudobeyrichi.-This species is quite uniform in size and shape; no significant difference of length or growth index between samples is indicated. However in shallower samples (C-8 and C-15) the keel is extremely narrow (pl. 31, figs. 6, 7) while in deeper samples the keel is wide and fragile (pl. 31, figs. 3-5).

From the above descriptions, it appears that intraspecific variation follows no rules, but that each species varies in a different manner. However, where great size variation is shown, greatest abundance, maximum size, rate of growth, and flare occur at depths of $800-900$ meters, as in samples $\mathrm{C}-9$ and $\mathrm{C}-14$.

\section{ECOLOGIC FACTORS}

The two traverses cross two different ecologic provinces: the continental shelf and the continental slope. Physicochemical factors affecting foraminiferal populations are considerably different in these two provinces.

On the shelf (where Bolivina species are small, and specific content varies rapidly with relatively slight depth changes) all of the following factors must be considered: light, turbulence, bottom flora, rapidly changing temperature, salinity, $\mathrm{pH}$, oxygen content, and organic content of the sediments.

On the slope (where the Bolivina species are large and there is little change in species content with great change in depth) two of the factors that must be considered on the shelf are not important. These factors are light, and flora. In addition, salinity shows no change, $\mathrm{pH}$ and temperature very little.

Variation which does occur on the slope is intraspecific. Specimens reach a maximum size, flare, height of chamber, and abundance at 800-900 meters (samples $\mathrm{C}-9$ and $\mathrm{C}-14$ ). This depth coincides with the oxygen minimum and the nitrogen maximum. Whether the large size of forms at this depth is due to favorable or to adverse conditions is uncertain. Recent work by Bradshaw (1957) indicates that large size and high chambers in the species Streblus beccarii var. tepida are a result of slow growth and unfavorable conditions. However, the greater aburdance of specimens, living and dead, at the oxygen minimum indicates that conditions were probably favorable.

The species present on the slope are dissimilar. Bolivina subadvena is thick shelled with coarse pores. Bolivina pseudobeyrichi is fragile, thin shelled, with extremely fine pores. Possibly these structural differences are a reflection of different microenvironments: $B$. subadvena may live in the sediments, while $B$. pseudobeyrichi may float on top of them by means of its wide keel. Work must be done with living specimens to determine the environments inhabited by each of these species.

\section{APPLICABILITY OF RESULTS TO FOSSIL CENOZOIC FORMS}

The quantitative data on species reported here may prove useful in identifying or delimiting the same or related species occurring in Cenozoic rocks of the Pacific coast, western North America, and elsewhere. Before the data can be used with any assurance, however, similar studies should be made of other Recent faunas containing the same or related species.

More generally, this study suggests that quantitative studies of well-preserved Tertiary Foraminifera may be helpful in establishing species and also in studying variation within species, in the hope of providing new data relative to paleoecological problems.

\section{SELECTED BIBLIOGRAPHY}

Arnold, Zach, 1953a, An introduction to the study of movement and dispersal in Allogromia laticollaris Arnold: Cushman Found. Foram. Research Contr., v. 4, p. 15-21.

__ 1953b, Paleontology and the study of variation in living Foraminifera: Cushman Found. Foram. Research Contr., v. 4 , p. 24-26.

1954a, Discorinopsis aguayoi (Bermudez) and Discorinopsis vadescens Cushman and Bronnimann: a study of variation in cultures of living Foraminifera: Cushman Found. Foram. Research Contr., v. 5, p. 4-13.

1954b, Variation and isomorphism in Allogromia laticollaris: a clue to foraminiferal evolution: Cushman Found. Foram. Research Contr., v. 5, p. 78-87.

1956, The contributions of Jean Le Calvez to the study of the 'Foraminifera: Cushman Found. Foram. Research Contr., v. 7, p. 1-14.

Bandy, O. L., 1953, Ecology and paleoecology of some California Foraminifera; Part I, The frequency distribution of Recent Foraminifera off California: Jour. Paleontology, v. 27 , p. 161-182.

1954, Distribution of some shallow-water Foraminifera in the Gulf of Mexico: U.S. Geol. Survey Prof. Paper 254-F, p. 123-141.

Bandy, O. L., and Arnal, R. E., 1957, Distribution of Recent Foraminifera off west coast of Central America: Am. Assoc. Petroleum Geologists Bull., v. 41, p. 2037-2053. 
Bradshaw, J. S., 1955, Preliminary laboratory experiments on ecology of foraminiferal populations: Micropaleontology, v. 1, p. $351-358$.

-__ 1957, Laboratory studies on the rate of growth of the foraminifer, "Streblus beccarii (Linne) var. tepida (Cushman )": Jour. Paleontology, v. 31, p. 1138-1147.

Brotzen, F., 1953, Problems in the nomenclature of the Foraminifera: The Micropaleontologist, v. 7, no. 2, p. 35-38.

Burma, B. H., 1948, Studies in quantitative paleontology; I, Some aspects of the theory and practice of quantitative invertebrate paleontology: Jour. Paleontology, v. 22, p. 725-761.

-__ 1949, Studies in quantitative paleontology; II, Multivariate analysis-a new analytical tool for paleontology and geology: Jour. Paleontology, v. 23, p. 95-103.

___ 1953, Studies in quantitative paleontology; III, An application of sequential analysis to the comparison of growth stages and growth series: Jour. Geology, v. 61, p. 533-543.

Coryell, H. N., and Mossman, R. W., 1942, Foraminifera from the Charco Azul formation, Pliocene, of Panama: Jour. Paleontology, v. 16, p. 233-246.

Crouch, R. W., 1952, Significance of temperature on Foraminifera from deep basins off southern California coast: Am. Assoc. Petroleum Geologists Bull., v. 36, p. 807-843.

Cushman, J. A., 1910, 1911, 1913, 1914, 1915, 1917, Foraminifera of the North Pacific Ocean: U.S. Natl. Mus. Bull. 71.

$\longrightarrow$ 1922, Shallow-water Foraminifera of the Tortugas region: Carnegie Inst. Washington Pub., v. 17, Pub. 311, p. $1-85$.

1926, Some Pliocene Bolivinas from Califormia: Cushman Lab. Foram. Research Contr., v. 2, p. 40-47.

1927, Recent Foraminifera from off the west coast of America : Scripps Inst. Oceanography Bull., Tech. Ser., v. 1, no. 10 , p. $119-188$.

- 1937, A monograph of the subfamily Virgulininae: Cushman Lab. Foram. Research, Spec. Pub. no. 9, 228 p.

- 1948, Foraminifera, their classification andeconomic use [4th ed.] : Cambridge, Mass., Harvard Univ. Press, 605 p.

Cushman, J. A., and Harris, R. W., 1927, The significance of relative measurements in the study of Foraminifera : Cushman Lab. Foram. Research Contr., v. 2, p. 92-94.

Cushman, J. A., and McCulloch, Irene, 1942, Some Virgulininae in the collections of the Allen Hancock Foundation-Reports on the rollections obtained by Allen Hancock Pacific Expeditions of Velero $I I I$ off the coast of Mexico, Central America, South America, and Galapagos Islands, 19321941 : Allen Hancock Pacific Expeditions, 1st ser., v. 6, no. 4, p. 179-230.

Cushman, J. A., and Todd, M. R., 1941, Statistical studies of some Bolivinas: Cushman Lab. Foram. Research Contr., v. 17, p. 29-31.

Glaessner, Martin F., 1955, Taxonomic, stratigraphic, and ecologic studies of Foraminifera and their interrelations: Micropaleontology, v. 1, p. 3-8.

Göes, Axel, 1896, The Foraminifera (Reports on the dredging operations off the west coast of Central America to the Galapagos, to the west coast of Mexico, and in the Gulf of California, in charge of Alexander Agassiz, carried on by the U.S. Fish Commission steamer Albatross, during 1891, Lt. Comdr. Z. L. Tanner, U.S. Navy, commanding) : Harvard Coll. Mus. Comp. Zoology Bull., v. 29, no. 1, p. 1-103.
Haynes, John, 1954, Taxonomic position of some British Palaeocene Buliminidae: Cushman Found. Foram. Research Contr., v. 5, p. 185-191.

Hiltermann, H., 1956, Ten rules concerning the nomenclature and classification of the Foraminifera: Micropaleontology, v. 2, p. 296-298.

Höglund, Hans, 1947, Foraminifera in the Gulmar Fjord and the Skagerak: Zool. Bidrag från Uppsala, v. 26, p. 1-328.

Hubbs, C. L., and Hubbs, Clark, 1953, An improved graphical analysis and comparison of series of samples: Systematic Zoology, v. 2, p. 49-57.

Hubbs, C. L., and Perlmutter, A., 1942, Biometric comparison of several samples, with particular reference to racial investigations : Am. Naturalist, v. 76, p. 582-592.

Imbrie, John, 1956, Biometrical methods in the study of invertebrate fossils : Am. Mus. Nat. History Bull., v. 108, art. 2, p. 211-252.

Kermack, K. A., 1954, A biometrical study of Micraster coranguinum and $M$. (Isomicraster) senonensis: Royal Soc. London Philos. Trans., Ser. B, Biological Sciences, no. 649, v. 237, p. 375-428.

Le Calvez, Jean, 1953, Ordre des Foraminifères, in Grasse, P., Traite de zoologie: Paris, Masson et Cie, v. 1, pt. 2, p. 149 270.

Mayr, Ernst, Linsley, E. G., and Usinger, R. L., 1953, Methods and principles of systematic zoology: New York, McGrawHill Book Co., 328 p.

Miller, R. L., 1949, An application of the analysis of variance to paleontology : Jour. Paleontology, v. 23, p. 635-640.

Myers, E. H., 1935, The life-history of Patellina corrugata Williamson, a Foraminifer: Scripps Inst. Oceanography Bull., Tech. Ser., v. 3, p. 335-392.

1936, The life-cycle of Spirillina vivipara Ehrenberg. with notes on morphogenesis, systematics and distribution of the Foraminifera : Royal Micr. Soc. Jour., v. 56, p. 120146.

Natland, M. L., 1933, Temperature- and depth-distribution of some Recent and fossil Foraminifera in the southern California region: Scripps Inst. Oceanography Bull., Tech. Ser., v. 3, p. 225-230.

- 1938, New species of Foraminifera from off the west coast of North America and from the later Tertiary of the Los Angeles Basin: Scripps Inst. Oceanography Bull., Tech. Ser., v. 4, p. 137-164.

- 1950, 1940 E. W. Scripps Cruise to the Gulf of California, Part 4, Report on the Pleistocene and Pliocene Foraminifera: Geol. Soc. America Mem. 43, p. 1-55.

Nicol, David, 1944, New west American species of the foraminiferal genus Elphidium: Jour. Paleontology, v. 18, p. 172-185.

Otto, G. H., 1933, Comparative tests of several methods of sampling heavy mineral concentrates: Jour. Sedimentary Petrology, v. 3, p. 30-39.

Parker, F. L., 1954, Distribution of the Foraminifera in the northeastern Gulf of Mexico: Harvard Coll. Mus. Comp. Zoology Bull., v. 3, no. 10, p. 453-588.

Phleger, F. B., and Parker, F. L., 1951, Ecology of Foraminifera, northwest Gulf of Mexico: Geol. Soc. America Mem. 46 , pt. 1, p. 1-88; pt. 2 , p. 1-64.

Russell, I. C., 1910, Volcanoes of North America: New York, McMillan Co., 346 p.

Scripps Institution of Oceanography, 1956, Data collected by Scripps Institution vessels on Eastropic Expedition, September to December, 1955: Scripps Inst. Oceanography Reference 56-28, $156 \mathrm{p}$. 
Simpson, G. G., 1940, Types in modern Taxonomy: Am. Jour. Sci., v. 238, p. 413-431.

1941, Range as a zoological character: Am. Jour. Sci., v. 239, p. 785-804.

Simpson, G. G., and Roe, Anne, 1939, Quantitative zoology: New York, McGraw-Hill, 414 p.

Sylvester-Bradley, P. C., 1956, The species concept in paleontology: The Systematics Assoc., Pub. no. 2, British Nat. History, London.

Walton, W. R., 1952, Techniques for recognition of living Foraminifera: Cushman Found. Foram. Research Contr., v. 3, p. 56-60.

1955, Ecology of living benthonic Foraminifera, Todos Santos Bay, Baja California: Jour. Paleontology, v. 29, p. 952-1018.
Weller, J. M., 1949, Paleontologic classification: Jour. Paleontology, v. 23, p. 680-690.

Williams, Howel, and Meyer-Abich, Helmut, 1955, Volcanism in the southern part of El Salvador: California Univ. Pub. in Geol. Sci., v. 32, no. 1, p. 1-64.

Woodring, W. L., and Bramlette, M. N., 1950, Geology and Paleontology of the Santa Maria district, California: U.S. Geol. Survey Prof. Paper 222, 185 p.

Wooster, W. S., and Cromwell, T., 1958, An oceanographic description of the eastern tropical Pacific: Scripps Inst. Oceanography Bull., v. 7, p. 169-283. 



\section{INDEX}

[Italic numbers indicate descriptions]

\section{A}

Abundance, Bolivina (Bolivina) acuminata Page

Bolivina (Bolivina) argentea (Bolivina) bradyi.......-. 23, pls. 15, 19, 20 humilis.............. 16, pls. 2, 22, 23, 24, 27

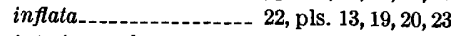
interjuncta bicostata...-.- pls. $5,19,20,21,23$ minuta...................... pls. 8, 24, 25 pacifica pseudobeyrichi.....- 22, pls. 14, 23, 24, 25, 26 seminuda........ 15, pls. 1, 22, 23, 24, 25, 27 semiperforata........ 18, pls. $6,24,25,26,27$ striatula............... 19, pls. 7, 19, 20 subadvena.-.-. 20, pls. $9,22,23,24,25,26,27$ tongi filacostata....- 21, pls. 10, 19, 20, 21, 23 vaughani................... 22, pls. 12, 19, 20

(Loxostomum) bolstovskoyi_... 23, pls. 16, 22, 23 salvadorensis............... 24, pls. 17, 22, 23

Suggrunda eckisi_-. 24, pls. 18, 19, 20, 21, 23, 24, 25, 27 Accumulation of faunas in place.............-. 25 Accumulation of samples.-_-_acerosa, Bolivina

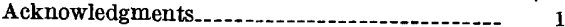
acuminata, Bolivina_-_._.-. 21, 25, 27

Bolivina subadvena.-_-_-_._-_._. 21 (Bolivina) _....-. 21, pls. 11, 19, 20, 21, 23, 28, 30 advena striatella, Bolivina...........alata, Bolivina beyrichi.

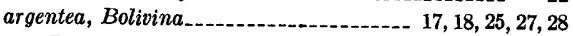

Bolivina (Bolivina) ........... 17, pls. 4, 24, 25, 28, 29 Asexual generation (schizont)............... 11

\section{B}

beccarii tepida, Streblus_._._._._._._. 13, 33 beyrichi, Bolivina beyrichi alata, Bolivina...-. 22 Bibliography bicostata, Bolivina costata...- 17 Bolivina interjuncta (Bolivina) interjuncta................ 17 ,

pIs. $5,19,20,21,23,28,30$

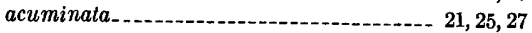
advena striatella.......................... 19

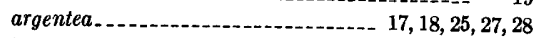
beyrichi-_-_-_-_.-. 23 alata

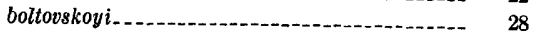
bradyi_... 28 bramlettei.-

costata bicostata

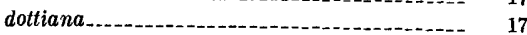
filacostata_._-_._.

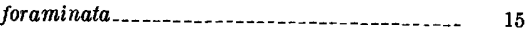
fragilis._._. 19 globulosa humilis..._._. 16, 27, 28

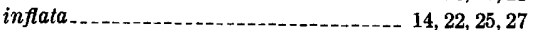

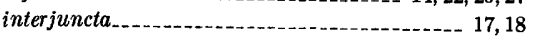
bicostata. . karreriana. . . mayori......- 24
Bolivina-Continued Page minuta ordinaria

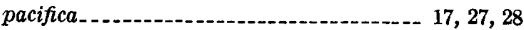

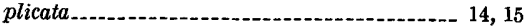
pomposa.

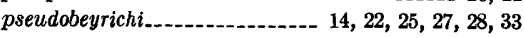

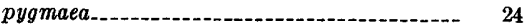

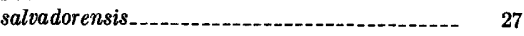

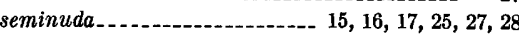
foraminata..........-...-. 15 semiperforata.................. 14, 18, 19, 25, 27, 28 spissa. striatula

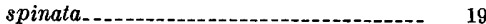
subadvena_..................... 20, 21, 25, 27, 28, 33 acuminata._......... 21 serrata.-.-_- 21

tongi-1-.--.-- 21 filacostata_-_._. 21, 27, 28

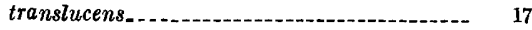
vaughani........... 22, 25, 27 (Bolivina) acuminata-.............. 21 , pls. 11, 19, 20, 21, 23, 28, 30 bradyi................. $2 s$, pls. $15,19,20,28,31$ humilis........ 16 , pls. $2,22,23,24,27,28,29$ inflata............. 22, pls. 13, 19, 20, 23, 28, 30 interjuncta bicostata................... pls. $5,19,20,21,23,28,30$ minuta $\ldots \ldots \ldots$.......... 19, pls. 8, 24, 25, 28, 30 pacifica_- 16 , pls. $3,19,20,21,23,24,26,27,28,29$ pseudobeyrichi _- 22 , pls. 14, $23,24,25,26,28,31$ seminuda....... 15 , pls. $1,22,23,24,25,27,28,29$ semiperforata....... 18 , pls. $6,24,25,26,27,28,30$ striatula.................. pls. 7, 19, 20, 28, 30 subadvena_._- 20, pls. $9,22,23,24,25,26,27,28,30$ tongi filacostata...- 21, pls. $10,19,20,21,23,28,30$ vaughani............... 22, pls. $12,19,20,28,30$ (Loxostomum) bolstovskoyi__-_-_._.-. 23, pls. $16,22,23,28,31$ salvadorensis_._._._._._. 24, pls. $17,22,23,28,31$ (Bolivina) acuminata, Bolivina...-........ 21 , pls. $11,19,20,21,23,28,30$ argentea, Bolivina........... 17, pls. 4, 24, 25, 28, 29 bradyi, Bolivina.............. 25, pls. 15, 19, 20, 28, 31 humilis, Bolivina_...... 16, pls. 2, 22, 23, 24, 27, 28, 29 inflata, Bolivina ......... 22, p.s 13, 19, 20, 23, 28, 30 interjuncta bicostata, Bolivina pls. $5,19,20,21,23,28,30$ minuta, Bolivina............ 19, pls. 8, 24, 25, 28, 30 pacifica, Bolivina pls. $3,19,20,21,23,24,26,27,28,29$ pseudobeyrichi, Bolivina.... 22, seminuda, Bolivina........ 15, pls. 1, 22, 23, 24, 25, 27, semiperforata, Bolivina pls. $6,24,25,26,27,28,30$ striatula, Bolivina_._._._._._19, pls. 7, 19, 20, 28, 30 subadvena, Bolivina........... 20 , tongi filacostata, Bolivina...-.-. -...-..... 21 , pls. $10,19,20,21,23,28,30$ vaughani, Bolivina _........ 22, pls. 12, 19, 20, 28, 30
Page

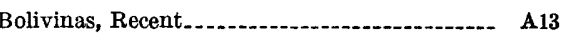
Bolivinidae_............... 1, 14, 27 Bolivinids....................... 10, 11, 25, 27 Bolivinita minuta.............................. 19 boltovskoyi, Bolivina Bolivina (Loxostomum) _..... 29, pls. 16, 22, 23, 28, 31 Loxostomum bradyi, Bolivina Bolivina (Bolivina) ........... 23, pls. 15, 19, 20, 28, 31 bramlettei, Bolivina

Calculations.-.-- 14 Coefficient of variability of sample............- 14, 28 Conclusions ...-.-.-.-. 25-33

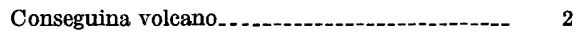

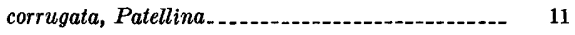
costata bicostata, Bolivina-_._-_-_-_-_-_-_-_ 17

$\mathrm{D}$

Description of sampled area..........- 2 Diagnostic features, Bolivina (Bolivina) acuminata......- 22 Bolivina (Bolivina) argentea............... 17 (Bolivina) bradyi_.............. 23, pls. 15, 19, 20

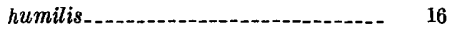
inflata interjuncta bicostata minuta._.

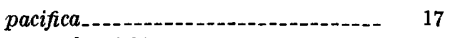
pseudobeyrichi_.._._. 23

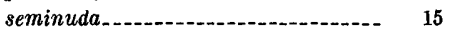
semiperforata...-_..- 18

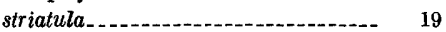
subadvena............................. 20 tongi filacostata_........- 21

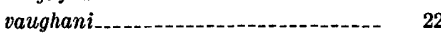

(Loxostomum) bolstovskoyi........-..-..-.- $\quad 24$ salvadorensis._._. 27

Suggrunda eckisi._...-. 25 Differentiation of species, statistical . .......... $\quad 27$

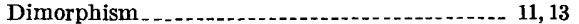
Distribution of bolivinids, ecologic factors...... 25

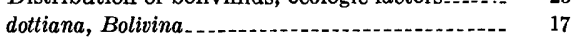
Downslope movements of faunas............. $\quad 25$

\section{$\mathbf{E}$}

Eastropic expedition eckisi, Suggrunda _. 24, 25, 27, 28, pls. 18, 19, 20, 21, 23, 24, $25,27,28,31$

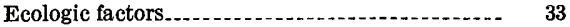
Ecologic variations within species............. 12 El Salvador Elphidiums.................................. 2

(25

Faunal uniformity ............... 27

filacostata, Bolivina.

Bolivina tongi .......................... 21, 27, (Bolivina) tongi_.21, pls. 10, 19, 20, 21, 23, 28, 30 
Page

Flare, Bolivina (Botivina) acuminata A21, pls. $11,19,20,21,23$ Bolivina (Bolivina) argentea.......... 17, pls. 4, 24, 25 (Bolivina) bradyi-_...-... 23, pls. 15, 19, 20 humvlis........-..-.- 16, pls. 2, 22, 23, 24, 27 inflata.................. 22, pls. 13, 19, 20, 23 interjuncta bicostata _- 18, pls. 5, 19, 20, 21, 23 minuta pacifica..... 17, pls. 3, 19, 20, 21, 23, 24, 26, 27 pseudobeyrichi.....- 23, pls. 14, 23, 24, 25, 26 seminuda semiperforata......... 18, pls. $6,24,25,26,27$ striatula ..................... 19, pls. 7, 19, 20 subadvena 20, pls. 9, 22, 23, 24, 25, 26,27 tongi filacostata..... 21, pls. 10,19, 20, 21, 23 vaughani-_............ 22, pls. 12, 19, 20 (Loxostomum) bolstovskoyi............... 24 pls. $16,22,23$ salvadorensis_............. 24, pls. 17, 22, 23 Suggrunda eckisi_. 25, pls. 18, 19, 20, 21, 23, 24, 25, 27 foraminata, Bolivina.

Bolivina seminuda

Foraminiferal studies, previous................. 2 Fossil Cenozoic forms, applicability of results...

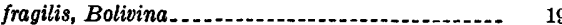

Gamont (sexual generation) globulosa, Bolivina............................... 22 Growth characteristics........................... 12, 13

Gulf of Fonseca

\section{H}

Hannibal, U.S. Navy ship......... 10 humilis, Bolivina ........................... 16, 27,28 Bolivina (Bolivina)---- 16, pls. 2, 22, 23, 24, 27,28, 29 Hydrographic data.

Hydrographic stations

Hypodigm of the species............................ 11

I

inflata, Bolivina............................. 14, 22, 25, 27 Bolivina (Bolivina).....- 22, pls. 13, 19, 20, 23, 28, 30 instabile, Loxostomum........................... 23, 24 interjuncta, Bolivina......... 17, 18 bicostata, Bolivina Bolivina (Bolivina) pls. $5,19,20,21.23,28,30$

Introduction

$\mathrm{K}$
karreriana, Bolivina
kleinpelli, Suggrunda

$\mathbf{L}$

Laboratory procedures and sampling technique_ Laboratory technique Length, Bolivina (Bolivina) acuminata ......... 21 pls. $11,19,20,21,23$ Bolivina (Bolivina) argentea........ 17, pls. 4, 24, 25 (Bolivina) bradyi.......... 23, pls. 15, 19, 20 humilis........... 16, pls. $2,22,23,24,27$ inflata interjuncta bicostata.............. 18 pls. $5,19,20,21,23$ minuta pacifica.. 16 , pls. $3,19,20,21,23,24,26,27$ pseudobeyrichi_......23, pls. 14, 23, 24, 25, 26 seminuda_...... 15 , pls. $1,22,23,24,25,27$ semiperforata 18 , pls. $6,24,25,26,27$ striatula ........... 19, pls. 7, 19, 20 subadvena... 20, pls. $9,22,23,24,25,26,27$ tongi filacostata.... 21, pls. 10, 19, 20, 21, 23 vaughani............... 22, pls. 12, 19, 20

(Loxostomum) bolstovskoyi_. _ 23, pls. 16, 22, 23 sudorensis _ _ 24 , pls. $17,22,23$ Suggrunda eckisi_. 24, pls. 18, 19, 20, 21, 23, 24, 25, 27
Living specimens, Bolivina (Bolivina) acuminata.......... A21, pls. 11, 19, 20, 21, 23 Bolivina (Bolivina) argentea.-...-. 27, pls. 4, 24, 25 (Bolivina) bradyi_........ 23, pls. 15, 19, 20 humilis............. 16, pl. 2, 22, 23, 24, 27 inflata ................ 22, pls. 13, 19, 20, 23 interjuncta bicostata............. 18 pls. $5,19,20,21,23$ minuta.................. 20, pls. 8, 24, 25 pacifica.. 17, pls. 3, 19, 20, 21, 23, 24, 26, 27 pseudobeyrichi_.... 23, pls. 14, 23, 24, 25, 26 seminuda_..... 15, pls. $1,22,23,24,25,27$ semiperforata....-. 18, pls. $6,24,25,26,27$ striatula subadvena.-- 20 , pls. $9,22,23,24,25,26,27$ tongi filacostata...- 21 , pls. $10,19,20,21,23$ vaughani................. 22, pls. $12,19,20$

(Loxostomum) bolstovskoyi_. _ 23, pls. 16, 22, 23 salvadorensis.............. 24, pls. 17, 22, 23 Suggrunda eckisi_. 25, pls. 18, 19, 20, 21, 23, 24, 25, 27 Loxostomum boltovskoyi_............. 27 instabile.

subrostratum

(Loxostomum) bolstovskoyi, Bolivina........-.-. 23, pls. $16,22,23,28,31$

salvadorensis, Bolivina _.. 24, pls. $17,22,23,28,31$

\section{M}

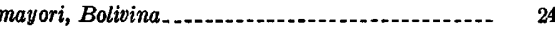

Mean length of sample.....

Measured samples.................................... 14

Measurements...................................... 12, 14

Methods of significance of statistical characterizations.

Micro-Kjeldahl method .................

minuta, Bolivina................................ 27, 28

Bolivina (Bolivina) _......... 19, pls. 8, 24, 25, 28, 30 Bolivinita

\section{$\mathrm{N}$}

Nansen bottles

Natural species.................

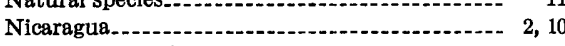
Nitrogen, organic

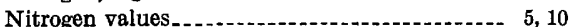
Number of chambers, Bolivina (Bolivina) acuminata . ............ 21, pls. 11, 19, 20, 21, 23

Bolivina (Bolivina) argentea __. 17, pls, 4, 24, 25 (Bolivina) bradyi....-.....-.-. 23, pls. 15, 19, 20 humilis............... 16, pls. 2, 22, 23, 24, 27 inflata interjuncta bicostata_. 18 , pls. $5,19,20,21,23$

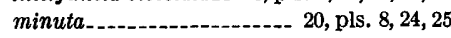
pacifica..... 16, pls. 3, 19, 20, 21, 23, 24, 26, 27 pseudobeyrichi ...... 23, pls. 14, 23, 24, 25, 26 seminuda......... 15, pls. $1,22,23,24,25,27$ semiperforata........ 18, pls. $6,24,25,26,27$ striatula subadvena.... 20, pls. $9,22,23,24,25,26,27$ tongi filacostata . .... 21, pls. 10,19, 20, 21, 23 vaughani-...-.-.-.-.-22, pls. 12, 19, 20

(Loxostomum) bolstovskoyi _. _ 24, pls. 16, 22, 23 salvadorensis_.............. 24, pls. 17, 22, 23

Suggrunda eckisi... 24, pls. 18, 19, 20, 21, 23, 24, 25, 27

\section{0}

Observed depth range, Bolivina (Bolivina) acuminata . . _....... 21, pls. $11,19,20,21,23$ Bolivina (Bolivina) argentea _........ 17, pls, 4, 24, 25 (Bolivina) bradyi............. 23, pls. 15, 19, 20 humilis.............- 16, pls. 2, 22, 23, 24, 27 infiata__._._._._. 22, pls. 13, 19, 20, 23 interjuncta bicostata.- 18 , pls. $5,19,20,21,23$ minuta
Page

Observed depth range, Bolivina (Bolivina)-Con. pacifica... A16, pls. 3, 19, 20, 21, 23, 24, 26, 27 pseudobeyrichi...... 22, pls. 14, 23, 24, 25, 26 seminuda semiperforata........ 18, pls. $6,24,25,26,27$ striatula_..._..._._._._. 19 , pls. $7,19,20$ subadvena..... 20, pls. $9,22,23,24,25,26,27$ tongi filacostata..... 21, pls. 10, 19, 20, 21, 23 vaughani-_ 22 , pls. $12,19,20$

(Loxostomum) bolstovskoyi_... 23, pls. 16, 22, 23 salvadorensis_._._......... 24, pls. $17,22,23$

Suggrunda eckisi_.. 24, pls. 18, 19, 20, 21, 23, 24, 25, 27

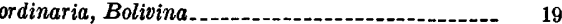
Organic nitrogren

pacifica, Bolivina Bolivina (Bolivina) pls. $3,19,20,21,23,24,26,27,28,29$

Patellina corrugata plicata, Bolivina_... 14, 15 pomposa, Bolivina.......................... 20,21 pseudobeyrichi, Bolivina

Bolivina (Bolivina) ..... 22, pls. 14, 23, 24, 25, 26, 28, 31

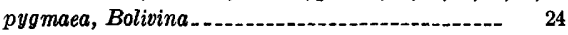

Qualitative criteria of morphology

Qualitative descriptions of morphologic charac-

Quantitative and qualitative analysis........... Quantitative data, Bolivina (Bolivina) acumi-

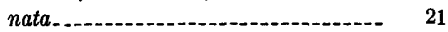

Bolivina (Bolivina) argentea..-.-.-.-.-.--.- 17

(Bolivina) bradyi_................ 23, pls. 15, 19, 20 humilis _. 16

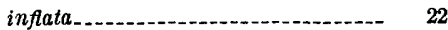
interjuncta bicostata.................. 18

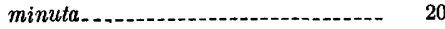
pacifica

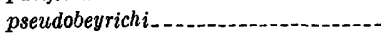
seminuda...

semiperforata

striatula.

subadvena.

tongi filacostata vaughani.

(Loxostomum) bolstovskoyi..................... salvadorensis

reproducibility. Suggrunda eckisi
Quantitative methods..........

Recent Foraminifera......- 2 Recent species of Foraminifera............ 11 Relation of sample to population. ............. 13-14 Rose bengal stain

salvadorensis, Bolivina........................... 27 Bolivina (Loxostomum) _..- 24, pls. 17, 22, 23, 28, 31 Samples, accumulation.-.................-..-- 27 coefficient of variability................... 14 indigenous accumulation. .........-..-...- 27 mean length.........-. 14 measured relation to population. standard deviation . transportation by downslope movements.--

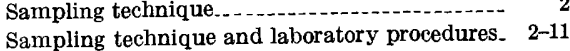
Schizont (asexual generation) -.................- 11 seminuda, Bolivina _... 15, 16, 17, 25, 27, 28 Bolivina (Bolivina) _ 15, pls. 1, 22, 23, 24, 25, 27, 28, 29 foraminata, Bolivina....................... 1 
Page

semiperforata, Bolivina_............. A 14, 18, 19, 25, 27, 28 Bolivina, (Bolivina) _. 18, pls. 6, 24, 25, 26, 27, 28, 30 serrata, Bolivina subadvena

Sexual generation (gamont)

Shuttle expedition.

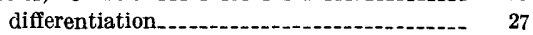

natural

statistical differentiation.................. 27-28

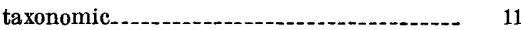

variation with depth........ 28-33

Spencer F. Baird, Scripps vessel.............. 1,2

spinata, Bolivina striatula........-...-....-. 19

Spirillina vivipara

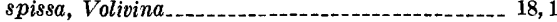

Standard deviation of sample................. 14, 25

Standard error of the mean................... 25

Statistical characterizations...-...-...-12-14

Statistical differentiation of species.......... 25, 27-28

Streblus beccarii te pida.................... 13, 33

striatella, Bolivina advena_..._-_._-_._-_ 19

striatula, Bolivina -

Bolivina (Bolivina) ......... 19, pls. 7, 19, 20, 28, 30

striatula spinata, Bolivina.

subadvena, Bolivina............... 20, 21, 25, 27, 28, 33

Bolivina (Bolivina)

pls. $9,22,23,24,25,26,27,28,30$ subadvena acuminata, Bolivina.

subadvena serrata, Bolivina.

Page

subrostratum, Loxostomum.......................

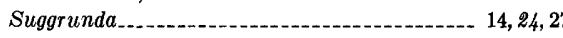

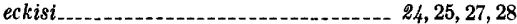
pls. $18,19,20,21,23,24,25,27,28,31$

klein pelli................-...-. 25 Systematic descriptions............................ 14-25

\section{$\mathrm{T}$}

Taxonomic species. 11

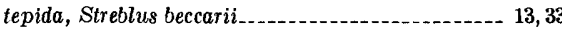
tongi, Bolivina.

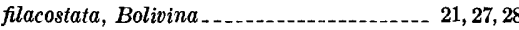
filacostata, Bolivina (Bolivina).......... 21, pls. $10,19,20,21,23,28,30$ translucens, Bolivina

Trends in Bolivina faunas................... 25 truncatum, Loxostomum

U

Uniformity of faunas.

Variation within species with depth
Page

vaughani, Bolivina ....... A22, 25, 27

Bolivina (Bolivina) _........ 22, pls. 12, 19, 20, 28, 30

vivipara, Spiri 11

W

Width, Bolvvina (Bolivina) acuminata.........- 21, pls. $11,19,20,21,23$

Bolivina (Bolivina) argentea...-.- 17, pls. 4, 24, 25 (Bolivina) bradyi_............23, pls. 15, 19, 20 humilis........... 16, pls. 2, 22, 23, 24, 27 inflata interjuncta bicostata.................. 18

pls. $5,19,20,21,23$ minuta pacifica_..- 17, pls. 3, 19, 20, 21, 23, 24, 26, 27 pseudobeyrichi_..... 23, pls. 14, 23, 24, 25, 26 seminuda_..... 15, pls. $1,22,23,24,25,27$ semiperforata_....... 18, pls. $6,24,25,26,27$ striatula _..._.......... 19, pls. 7, 19, 20 subadvena _... 20, pls. $9,22,23,24,25,26,27$ tongi filacostata $\ldots \ldots$... 21 , pls. 10, 19, 20, 21, 23 vaughani 22, pls. $12,19,20$

(Loxostomum) bolstovskoyi__._24, pls. 16, 22, 23 salvadorensis_._._._._... 24, pls. 17, 22, 23

Suggrunda eckisi............ 25 pls. $18,19,20,21,23,24,25,27$ 

PLATES 29-31 


\section{PLATE 29}

Figures 1-7. Bolivina (Bolivina) seminuda Cushman (p. A15)

1-5. Form with clear areas only on last chambers. 1, 2, megalospheric form, $\times 112$, USNM 626541: 1, apertural view; 2 , side view. 3,4 , microspheric form, $X 112$, USNM 626542: 3, apertural view; 4 , side view. 5 , dissected specimen, $\times 112$, USNM 626543 .

6, 7. Typical form, $\times 112$, USNM 626540: 6 , apertural view; 7 , side view.

8, 9. Bolivina (Bolivina) pacifica Cushman and McCulloch (p. A16).

USNM 626546, $\times 188: 8$, apertural view; 9 , side view.

10-13. Bolivina (Bolivina) humilis Cushman and McCulloch (p. A16).

10, 11. Megalospheric form, $\times 188$, USNM 626544: 10, apertural view; 11, side view.

12, 13. Microspheric form, $\times 188$, USNM 626545: 12 , apertural view; 13, side view.

14-17. Bolivina (Bolivina) argentea Cushman (p. A17).

14, 15. Microspheric form, $\times 112$, USNM 626547: 14, apertural view; 15, side view.

16, 17. Megalospheric form, $\times 112$, USNM 626548: 16 , apertural view; 17 , side view. 

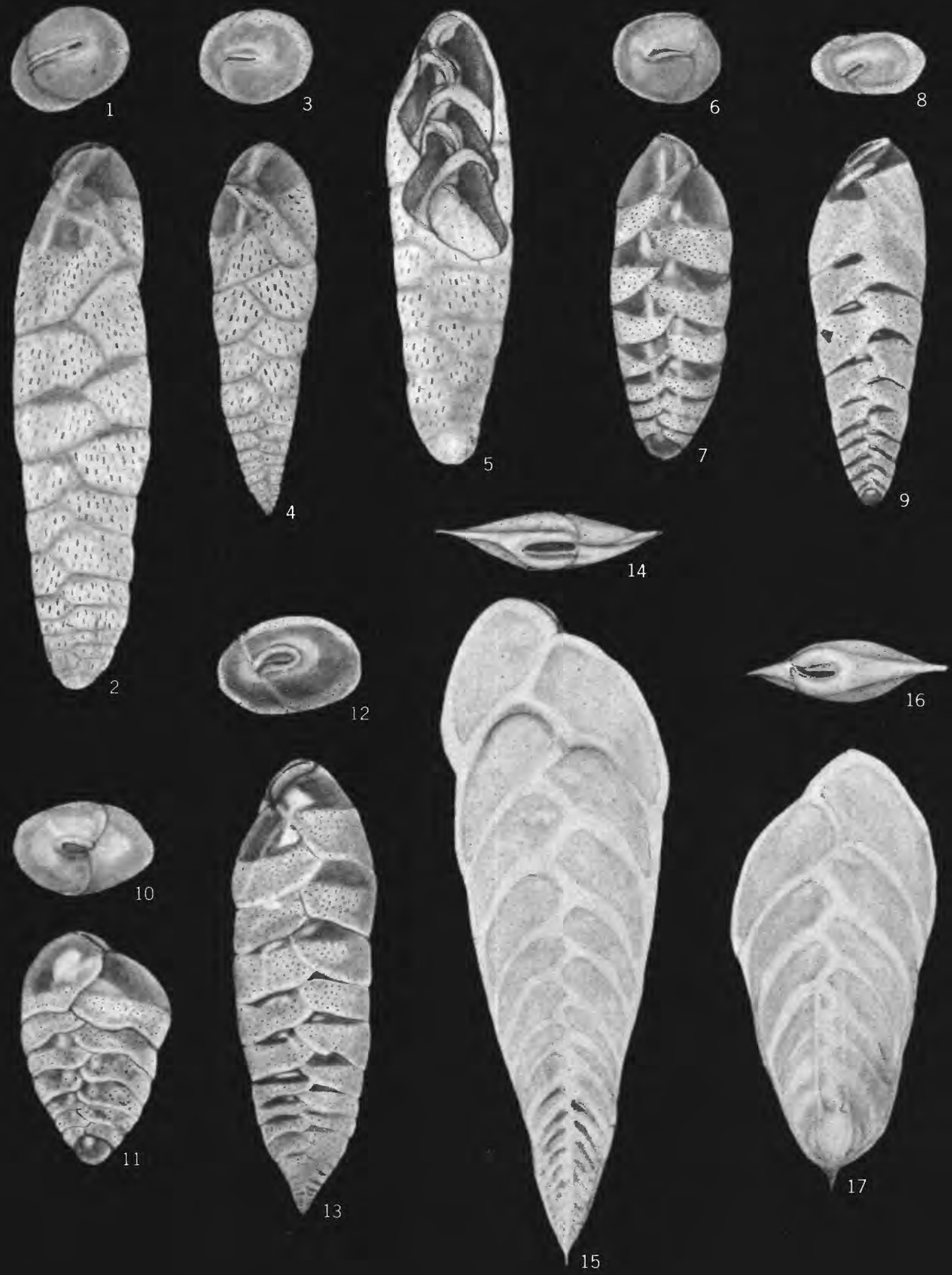


\section{PLATE 30}

Figures 1-4. Bolivina (Bolivina) interjuncta bicostata Cushman (p. A17).

1, 2. Megalospheric form, $\times 112$, USNM 626549: 1, apertural view; 2, side view. 3, 4, microspheric form, $\times 125$, USNM 626550: 3 , apertural view; 4 , side view.

5-8. Bolivina (Bolivina) semiperforata Lewis Martin (p. A18).

5, 6. Microspheric form, $\times 125$, USNM 626551: 5, apertural view; 6, side view. 7, 8, megalospheric form, $\times 125$, USNM 626552: 7 , apertural view; 8 , side view.

9-10. Bolivina (Bolivina) striatula Cushman (p. A19).

USNM 626553, $\times 188: 9$, apertural view; 10, side view.

11, 12. Bolivina (Bolivina) minuta Natland (p. A19).

USNM 626554, $\times 112: 11$, apertural view; 12 , side view.

13-17. Bolivina (Bolivina) subadvena Cushman (p. A20).

13, 14. Microspheric form, $\times 112$, USNM 626555: 13, apertural view; 14, side view.

15-16. Megalospheric form, $\times 112$, USNM 626556: 15 , apertural view; 16, side view. 17, dissected specimen, $\times 112$, USNM 626557.

18, 19. Bolivinia (Bolivinia) tongi filacostata Cushman and McCulloch (p. A21).

USNM 626558, $\times 112$ : 18, apertural view; 19, side view.

20-21. Bolivina (Bolivina) acuminata Natland (p. A21). USNM 626559, $\times 125: 20$, apertural view; 21 , side view.

22, 23. Bolivina (Bolivina) inflata Heron-Allen and Earland (p. A22). USNM 626561, X 188: 22, apertural view; 23, side view.

24, 25. Bolivina (Bolivina) vaughani Natland (p. A22). USNM 626560, X 188: 24, apertural view; 25, side view. 


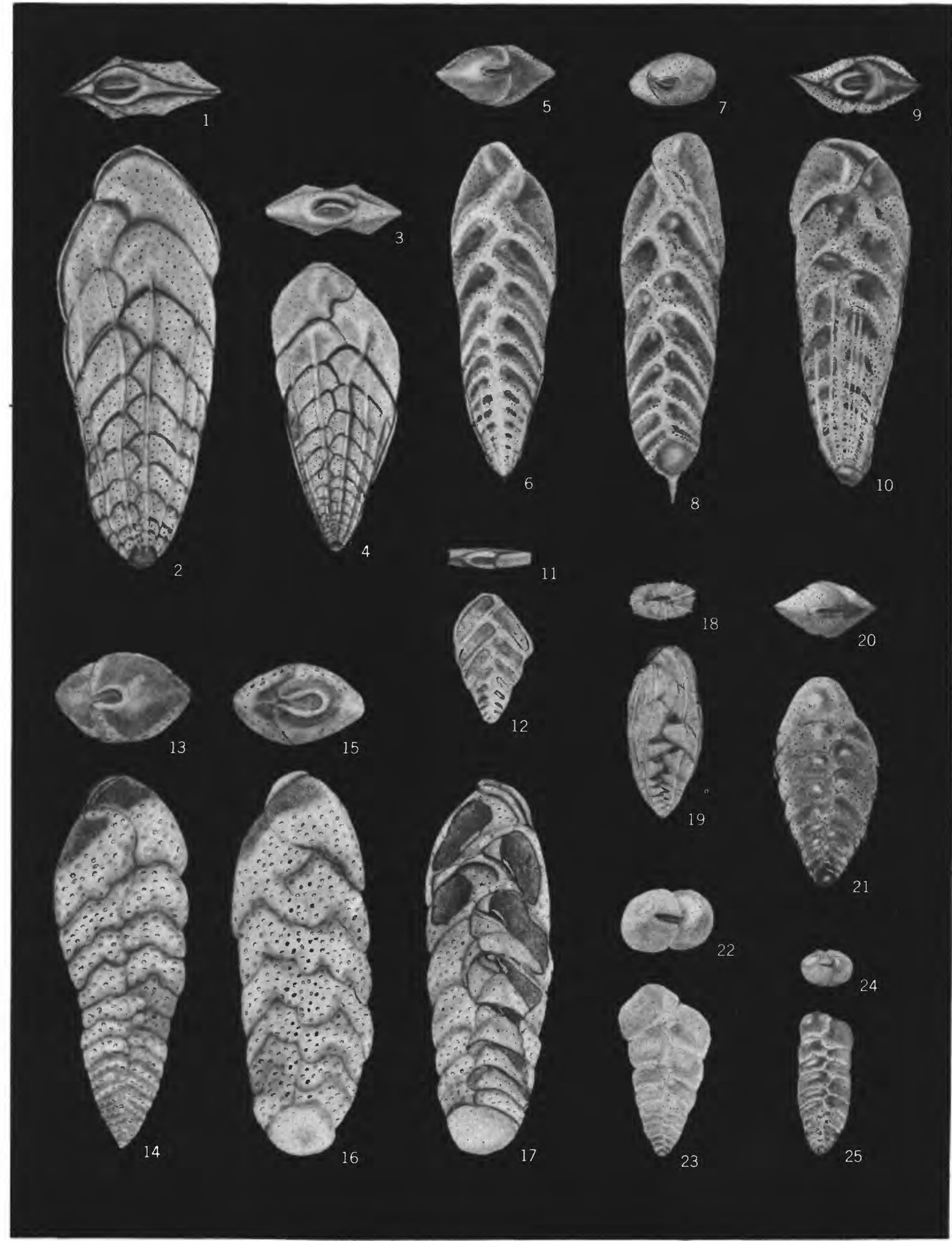




\section{PLATE 31}

Figures 1, 2. Bolivina (Bolivina) bradyi Asano (p. A23). USNM 626562, $\times 112$ : 1, apertural view; 2 , sidè view.

3-8. Bolivina (Bolivina) pseudobeyrichi Cushman (p. A22). 3-5. Wide-keeled form. 3, 4, megalospheric form, $\times 112$, USNM 626564: 3 , apertural view; 4 , side view; 5 , microspheric form, $\times 112$, USNM 626563, side view.

6, 7. Narrow.keeled form, $\times 112$, USNM 626566: 6, apertural view; 7 , side view.

8. Dissected specimen, $\times 112$, USNM 626565 .

9, 10. Bolivina (Loxostomum) boltovskoyi n. sp. (p. A23).

Holotype, USNM 626567, $\times 112: 9$, apertural view; 10 , sice view.

11, 12. Bolivina (Loxostomum) salvadorensis n. sp. (p. A24).

Holotype, USNM 626569, × 112: 11, apertural view; 12, side view.

13, 14. Suggrunda eckisi Natland (p. A24).

USNM 626571, $\times 188: 13$, apertural view; 14 , side view. 


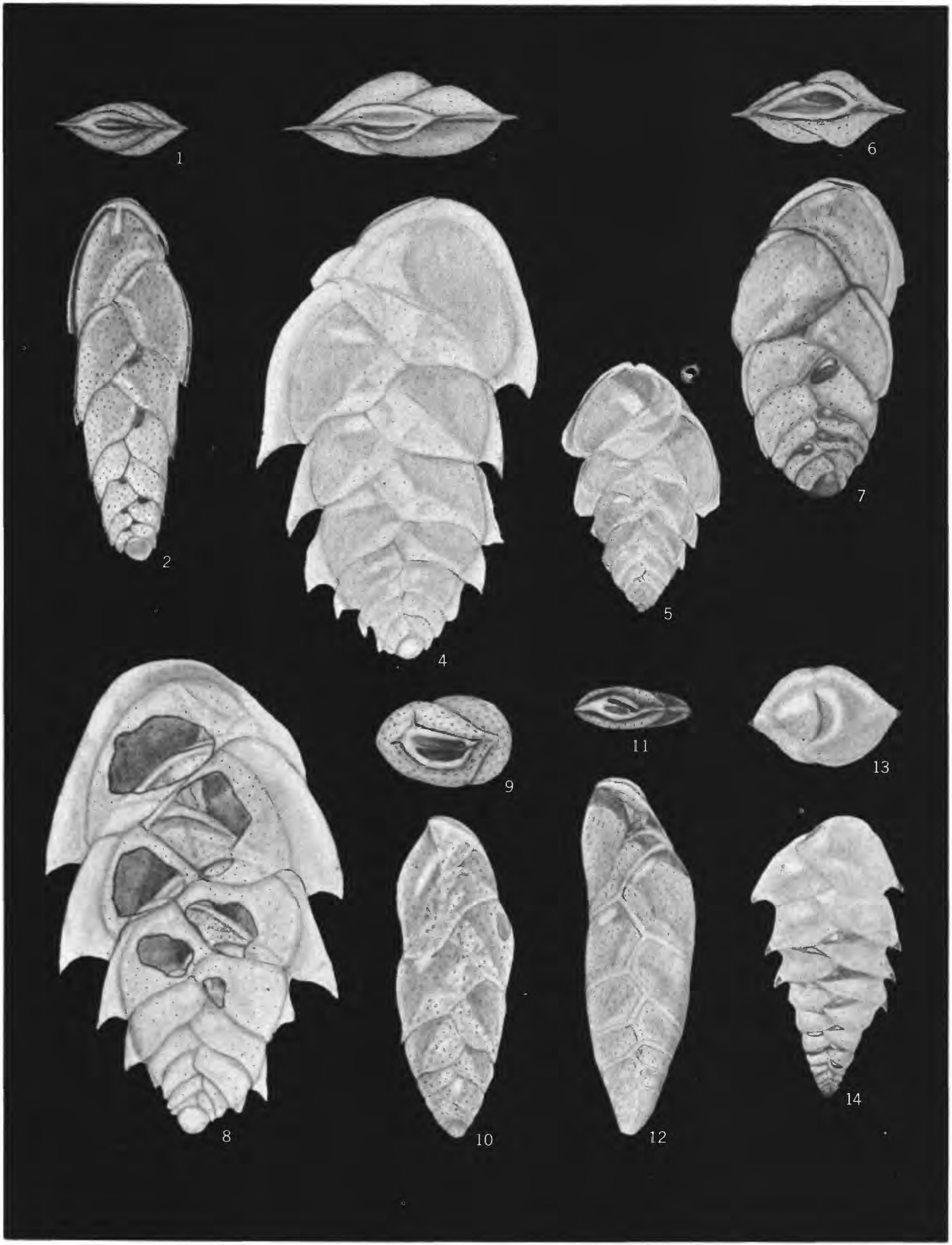

